\title{
La argumentación retórica en cuatro obras políticas de Quevedo: Grandes anales de quince días, Mundo caduco y desvaríos de la edad, Política de Dios y Primera parte de la vida de Marco Bruto ${ }^{1}$
}

\author{
Antonio Azaustre Galiana \\ Universidade de Santiago de Compostela \\ Dpto. de Literatura Española, Teoría de la Literatura \\ y Lingüística General \\ Facultad de Filología \\ Avda. Castelao s. / n. \\ 15782 Santiago de Compostela \\ antonio.azaustre@usc.es
}

[La Perinola, (Issn: 1138-6363), 21, 2017, pp. 151-206]

DOI: $10.15581 / 017.21 .151-206$

\section{El MARCo General}

El estudio de la argumentación es un aspecto de gran importancia para la cabal comprensión no solo de la literatura, sino de cualquier discurso. En el terreno literario, resulta especialmente fructífero aplicado a las obras políticas y morales, pues constituyen estas un tipo de literatura que se orienta de forma clara a la persuasión del lector en favor de una determinada tesis.

La dispositio o estructura y, dentro de ella, la argumentación, es una parte esencial de la retórica porque lo es del pensamiento y el lenguaje. En consecuencia, su estudio no debe tener un carácter exclusivamente formalista, como tampoco deberían tenerlo los del estilo si se enfocan adecuadamente. La argumentación revela los mecanismos mediante los cuales el escritor organiza las ideas y las plantea a lo largo de la obra: el argumento -como el rasgo de estilo- implica una determinada organización del contenido; conocerla y explicarla permite sostener con mucha más precisión los juicios sobre las ideas y temas de cada obra u autor.

1. Este trabajo se integra en las actividades del Proyecto de Investigación «El comentario filológico en el ámbito hispano entre los siglos xIII y XVII» (FFI2013-42357-P), financiado por el Ministerio de Economía y Competitividad. 
El método de estudio que aquí sigo se basa en la retórica clásica, en tanto constituye una disciplina fundamental en la formación de los escritores áureos y, en consecuencia, se adecua históricamente a su labor. No es necesario insistir en la formación retórica de Quevedo ni tampoco en su interés por esta disciplina, atestiguado, entre otras razones, por sus anotaciones a su ejemplar de la Retórica de Aristóteles o sus observaciones en los preliminares de sus ediciones de fray Luis de León y Francisco de la Torre. Claudio Guillén (1982, p. 504) ponderó esa afinidad entre Quevedo y esta ars al hablar de su poesía:

Quevedo se nos aparece como el más retórico de los grandes poetas españoles. Aquí el adjetivo «retórico» no es despectivo. No se trata de una oquedad o falta de sustancia. Todo lo contrario: el gran poeta retórico, porque es grande, convence $-\mathrm{o}$ al menos nos zarandea o emociona.

Mucha de esta habilidad para persuadir y mover afectivamente la encontraremos en su prosa política y moral, aunque estemos lejos del lirismo y la emoción del poema.

Al ponderar la complejidad del fenómeno de la argumentación, Christian Plantin (1998, p. 16) advertía del riesgo que plantea la multiplicidad de enfoques: «su diversidad puede hacer difícil esta aproximación». Aun reconociendo su importancia, no se emplearán otros enfoques que se han acercado a este objeto de estudio para no confundir perspectivas ni objetivos de análisis. Me refiero a las aportaciones que provienen de la nueva retórica (Perelman, 1994), la lógica (Hamblin, 1970; Blair y Johnson, 1980 y 1994; Woods y Walton, 1992; Van Eemeren y Grootendorst, 1992), la pragmática lingüística (Austin, 1982; Searle, 1994; Grice, 1991; Anscombre y Ducrot, 1994) e incluso el derecho².

2. El derecho y la política fueron los ámbitos de origen de la retórica, pero no conservan hoy la misma vinculación con ella. Los modernos acercamientos que desde la esfera del derecho se hacen a esta disciplina tienden más bien a historiar sus conexiones pasadas y a recordar los muchos puntos de convergencia y aprovechamiento que ofrece la retórica. Véanse, por ejemplo, Ghirardi, 2000 y 2001, y Rovira Flórez de Quiñones, 2004. Lógicamente, las aplicaciones a la actual esfera judicial quedan fuera de nuestros objetivos, y cabe solo lamentar la degradación de lo que debería llamarse oratoria forense o política. Los acercamientos provenientes de la lingüística y, más concretamente, de la semántica y la pragmática, tampoco parecen los más adecuados para este tipo de análisis de corte histórico. Frente a la gramática tradicional, que consideraba como función principal de la lengua representar la realidad, estos enfoques atienden a la vertiente más subjetiva y práctica del lenguaje y su significación. Su estudio del lenguaje -vinculado a su dimensión, finalidad e influencia social- afecta e interesa a fenómenos de la importancia de la publicidad o los medios de comunicación. Señalaré un ejemplo: dentro de la potenciación de esta visión subjetiva del lenguaje y su significación se inscribe la teoría de la argumentación de Anscombre y Ducrot. La evolución de sus teorías de 1983 se centra en el desarrollo de la noción de topos. Este concepto se modela sobre el de Aristóteles aunque, como indican los autores, se modifica y restringe en su extensión (Anscombre y Ducrot, 1994, p. 217: «topos, noción elaborada, por supuesto, a partir de la noción aristotélica; pero que está lejos de abarcar todo lo que Aristóteles y la retórica clásica incluían en ese término»). Me he detenido en este rasgo porque muestra con claridad el vínculo entre la 
En la retórica clásica, el estudio de la argumentación se sitúa dentro de las partes del discurso; pertenece, pues, a la dispositio, aunque también se vincula a la inventio, ya que el hallazgo de ideas y argumentos es consustancial en la retórica a las partes del discurso ${ }^{3}$. Aristóteles desarrolla lo referente al sistema de la argumentación en los libros 1 y 2 de su Retórica, donde destaca el estudio de los afectos; la Rhetorica ad Herennium lo trata en el libro 2, donde lo enfoca como un tratamiento adaptado a cada tipo de causa (judicial, deliberativa y demostrativa); Cicerón lo aborda en $D e$ inventione, libro 1, y lo vincula a las partes del discurso pues, como se ha dicho, el hallazgo de las ideas y argumentos más adecuados dependerá de qué parte del discurso se esté tratando; por último, Quintiliano ofrece un detenido estudio en el libro 5 de su monumental Institutio Oratoria ${ }^{4}$. También los ejercicios retóricos - progymnasmata o praexercitamina- enseñaban muchas de las técnicas de argumentación, como la refutación, la confirmación, el lugar común o la tesis ${ }^{5}$.

Intentando sistematizar los planteamientos de los anteriores tratados, podemos decir que la argumentación distingue, en primer lugar, entre las pruebas inartísticas y las artísticas: las primeras son las que no precisan de la retórica para construirse, pues son proporcionadas directamente por la causa o asunto tratados; se trata de los contratos, documentos y leyes (praeiudicia), testigos y confesiones. Esta esfera de pruebas no está, sin embargo, tan alejada de la manipulación retórica como su nombre pueda indicar. A menudo se aduce un documento, testimonio o confesión que es 'acercado' por el orador al asunto concreto y la posición que se defiende, lo que muestra cómo las pruebas inartísticas son susceptibles de ser manipuladas por el arte retórica.

Las pruebas artísticas son las que se construyen con el auxilio de la retórica; dentro de ellas se distinguen dos grandes esferas: la subjetiva (o afectiva) y la objetiva. La importancia de la esfera afectiva queda demostrada al comprobar que una de las principales razones que parece impulsaron a Aristóteles a realizar una segunda redacción de su Retórica fue la inclusión de esta vertiente ${ }^{6}$. Dentro de ella, los recursos podían

preceptiva clásica y la teoría lingüística en cuestión; esta última parte de sus presupuestos, y los modifica y actualiza desarrollando nuevos conceptos y enfoques, propios de una perspectiva y tiempo distintos.

3. De hecho, tratados como la Rhetorica ad Herennium desarrollan conjuntamente ambas dimensiones.

4. La tradición retórica griega postaristotélica (Demetrio, Dionisio, Hermógenes) tuvo también una gran influencia en nuestro Siglo de Oro (López Grigera, 1994). Aunque no desconoció las aportaciones sobre la argumentación, como muestra el libro tercero de la

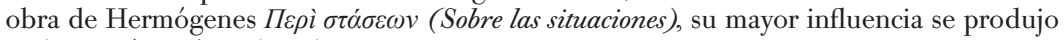
en las teorías sobre el estilo.

5. La influencia del ramismo en la enseñanza retórica durante los siglos XVI y XVII y su reducción de la retórica a la elocutio no implica el desconocimiento de estas cuestiones; en primer lugar, porque no todas las retóricas de influencia en la época tenían esta orientación; en segundo lugar, porque la dialéctica se ocupaba de ellas.

6. Los expertos en la obra del Estagirita señalan que es posible que partiese de un concepto de la argumentación retórica de índole logicista, esto es, muy cercano a los 
provenir del talante del orador -que debía presentarse como fidedigno- y de la adecuada moción de las pasiones de los oyentes en relación con las ideas que se deseaban transmitir.

En las pruebas objetivas se distinguían los signos, los argumentos y los exempla. Los signos son señales que, de manera más o menos segura (necessaria o non necesaria) implican un determinado hecho; por ejemplo, las olas como signo de viento en el mar?. El campo de los argumentos, amplio y complejo, da cabida a los raciocinios y el sistema de los loci (estudiados en la inventio, pero también aquí cuando se aplican a la construcción de un argumento). Los raciocinios (silogismos, entimemas o epiqueremas) construyen un razonamiento lógico sobre una base 'segura. A partir de dicha premisa -y con mayor o menor garantía dependiendo de su seguridad- se ha de levantar un razonamiento verosímil por deducción. El conocido sistema de los loci - a persona y a $r e$, con amplia tipología en ambos campos- proporciona una completa casuística de ideas para aplicar a las más diversas circunstancias y asuntos, cuya importancia en la literatura concebida al amparo de la imitatio está más que sobradamente comprobada ${ }^{8}$.

La tradición de los exempla, fundamental en los ejercicios retóricos, aprovecha el relato de un suceso concreto y externo al asunto para, mediante la analogía, extraer una enseñanza por inducción. Los campos de la mitología y, sobre todo, la historia clásica y sagrada, ofrecerán un amplio abanico de sucesos de los que extraer dichas enseñanzas. Cercanas al exemplum se encuentran las citas y sentencias de autoridades, susceptibles de ser elaboradas retóricamente a favor de la argumentación defendida, algo que se enseñaba en los ejercicios retóricos de la chría y la sententia ${ }^{9}$.

planteamientos de la dialéctica. Según este enfoque, los recursos de argumentación provendrían exclusivamente de los asuntos del discurso. Al ponderar el hecho de que este enfoque dejaba de lado el campo de los afectos, de gran importancia en la persuasión, la segunda redacción habría dado cabida a los recursos argumentativos relacionados con el talante del orador y las pasiones de los oyentes, que se ubican en Retórica (2, 1-18). Véase Racionero, en Aristóteles, Retórica, pp. 10-11 y 110 y ss.

7. Especial relieve en la literatura adquieren los signa amoris: languidez y delgadez del rostro, falta de apetito, distracción.

8. Basta mencionar, para la tópica tradicional, el clásico trabajo de Curtius, 1981. Son evidentes sus conexiones con la dialéctica, parcela de la filosofía que se ocupaba de la capacidad racional de investigar, definir y exponer, y que enseñaba a delimitar lo verdadero y lo falso mediante el contraste de argumentos. También la tópica pertenecía a esa esfera, pero autores como Aristóteles y Quintiliano incorporaban esas vertientes de la dialéctica a la inventio retórica. Este punto de contacto entre dialéctica y retórica resultó fuente de fricciones. Conocida es la separación de ambas en el ramismo, clave en la visión negativa de la retórica como una vacía lista de tropos y figuras.

9. chría: «es la mención de un dicho o acción, o de lo uno y lo otro, que tiene una exposición concisa y que tiende generalmente hacia algo útil. Ejemplo del tipo mixto: Diógenes, al ver a un joven maleducado, golpeó a su pedagogo diciéndole, ìpor qué, pues, le enseñas tales cosas?» (Hermógenes, p. 179); sententia: «es una máxima expresada en una enunciación general, que desaconseja algo o exhorta hacia algo que pone de mani- 
Este sistema de la argumentación, conocido habitualmente como probationes, se enriquece con diversos elementos retóricos que contribuyen a reforzarlo en mayor o menor medida. Se trata de la amplificación, los loci communes y el ornatus a través de los tropos y figuras. La amplificación ofrece una completa tipología de recursos para intensificar cuantitativa y cualitativamente aquellas ideas y argumentos que se considere necesario reforzar: acumulación enumerativa, técnicas de incrementum, comparaciones intensificadoras de menos a más o viceversa... Los lugares comunes son ideas de carácter general e infinito que pueden ser aplicados en muchos asuntos (de ahí el calificativo). Ese valor general les hace también susceptibles de refrendar y reforzar los argumentos concretos que han sido desarrollados, por lo que pueden ser estudiados como una forma más de amplificación. Por ejemplo, después de argumentar en contra de una intervención militar concreta, dicho punto de vista -que se ha sostenido en argumentos referentes al hecho particular- puede intensificarse con ideas generales contra la guerra. Finalmente, el uso no habitual del lenguaje que caracteriza a tropos y figuras logra un embellecimiento de la expresión (ornatus) que lo vuelve más atractivo; pero ese atractivo se orienta también a la persuasión, de manera especial en los asuntos y géneros literarios que poseen una finalidad práctica, como es el caso de los que se estudian aquí1 $^{10}$. Esta finalidad de tropos y figuras más allá de la belleza literaria entronca con su presencia original en el discurso y disciplina retóricas, orientados a la persuasión. En la literatura política, moral y religiosa, esta vertiente desempeña un papel fundamental ${ }^{11}$.

Con estos presupuestos de partida, este trabajo analizará la argumentación retórica en algunas obras políticas de Quevedo. Su finalidad es insistir en el carácter auxiliar de la retórica como disciplina que sirve para entender los textos en la historia y, en este caso, explicar las posibilidades del sistema de la argumentación retórica y sus repercusiones en la organización de los textos, lo que permite una mejor comprensión de su sentido ${ }^{12}$. No abordaré la argumentación de otras obras de Quevedo de las que ya me he ocupado en trabajos anteriores, pero que completarían el panorama aquí trazado ${ }^{13}$.

fiesto el carácter de cada cosa. Desaconsejando, como aquel pasaje: No ha de dormir toda la noche un hombre que toma decisiones» (Hermógenes, p. 181).

10. Para la importancia del ornatus en la argumentación, véase Lausberg, 1984, §§ 427 y 538

11. Esa capacidad argumentativa de tropos y figuras es también reivindicada por la nueva retórica (Perelman, 1994, pp. 268-285).

12. Al estudiar cómo estructuraba Quevedo sus obras, y de qué manera se enfrentaba a las fuentes y géneros literarios, se oscila en ocasiones entre un Quevedo riguroso y esmerado, o uno más dado a la yuxtaposición de brillantes agudezas. Véase el repaso que de estas opiniones hace Riandière La Roche, 2000, pp. 345-350, donde se subraya la necesidad de entender al escritor y sus textos en la historia.

13. Me refiero al Memorial por el patronato de Santiago, Su espada por Santiago, Lince de Italia u zahorí españoly, aunque de carácter menos explícitamente político, España defendi- 


\section{Historia y POLÍtica}

Varias obras de Quevedo se organizan como un relato de diversos sucesos históricos que incorpora sus juicios políticos sobre ellos. Su figura de intelectual y escritor convive con la de un activo protagonista de la realidad política de su tiempo. Del cruce de ambas esferas surgen estas obras que combinan el relato historiográfico con la reflexión política y moral. Tal vez el historiador nunca se vea libre de la subjetividad que interpreta la historia desde sus valores, pero en Quevedo prima el talante político que se sirve de la historia para orientarla en favor de sus intereses ${ }^{14}$. Esta actitud implica un trabajo argumentativo del texto, que en estas obras debe aplicarse al entramado narrativo que lo sostiene. Grandes anales de quince días y Mundo caduco y desvaríos de la edad ejemplifican este modo de proceder.

\section{Grandes anales de quince días}

Como es sabido, esta obra relata los acontecimientos históricos que tuvieron lugar entre la muerte de Felipe III (31 de marzo de 1621) y el nombramiento de Pedro de Contreras como Secretario de Estado (10 de marzo de 1623). Su estructura consta de tres grandes secciones: dos preliminares literarios, la narración de los hechos y una breve galería de retratos de reyes y ministros del período en cuestión ${ }^{15}$.

Victoriano Roncero (1988, pp. 149-197 y 2005, pp. 45-49) ha analizado las fases de redacción a las que fue sometida la obra por parte de Quevedo, y concluye que existieron tres redacciones: una primera concluida sobre marzo o abril de 1623, una segunda en los primeros meses de 1624 y una tercera en los primeros años de la década de $1630^{16}$. Se trata, pues, de una crónica escrita con la necesaria cercanía y adaptación

da. Para su análisis, véanse, Azaustre, 1997, 2000, 2004a y 2012. Véanse también Alonso Veloso, 2002 y 2004, y Escobar Borrego, 2012, 2013 y 2015.

14. Ettinghausen, 1995, y Fernández Mosquera, 1998, han mostrado palmariamente la consciente e interesada mezcla y transgresión de géneros que lleva a cabo Quevedo en muchas de sus obras para transmitir con mayor eficacia su ideología. La utilización política de la historia por parte de Quevedo ha sido constatada por la crítica; véase, por ejemplo, Riandiére, 1994, p. 977: “Es evidente al menos que utilizó la historia, "grande" o "pequeña", historia de un pasado lejano o historia "inmediata", para escribir de política, según el concepto que se tenía de la historia en aquella época».

15. Sobre el período de transición entre los reinados de Felipe III y Felipe IV, véanse, entre otros, Biurrun Lizarazu, en Quevedo, Mundo caduco, pp. 15-33; Elliott, 1982; Ettinghausen, 1997 y 1998; Jauralde, 1998, pp. 430-431; Juárez, 1990, pp. 158-192; Peraita, 1997, y Roncero, 1988 y 1991. Véase también el estudio que Jauralde, 1998, pp. 429-454, hace de esta obra dentro de la biografía de Quevedo.

16. Me atendré al texto de la última redacción, editado por Roncero, 2005. La aportación principal de la segunda redacción es la incorporación de los retratos de reyes y ministros, que ilustran la relación de hechos históricos; el cambio más significativo de la tercera redacción es la supresión de varios párrafos donde se elogia la labor de Felipe IV y Olivares, rasgo interpretado como muestra del progresivo alejamiento de Quevedo de la política de ambos. 
al devenir de los sucesos, y que probablemente quedó inconclusa (Rey, 2005 , p. xxxvIII). Es este un rasgo que ya se observa en la temprana España defendida, y que se repetirá en otras obras de Quevedo, como Mundo caduco y desvaríos de la edad.

El título es un ejercicio de concentración expresiva y agudeza, dos rasgos característicos del usus scribendi de Quevedo. Dejando a un lado los ecos de los Anales de Tácito, el oxímoron que provoca el contraste entre los dos sintagmas hiperboliza la alabanza del nuevo monarca, capaz de logros extremos en un breve lapso de tiempo; al mismo tiempo, muestra la intrínseca dificultad de la prosa quevediana, y aleja la obra de la más sencilla prosa de las relaciones, panfletos y demás modalidades publicistas, anunciando un escrito de pretensiones historiográficas más elevadas ${ }^{17}$.

La primera dedicatoria se dirige «A los señores príncipes y reyes que sucederán a los que hoy son en los afanes de este mundo». En ella se enfoca la obra no solo como una crónica de hechos históricos, sino también con una finalidad didáctica vinculada a la antigua tradición del regimiento de príncipes. Esa finalidad se completa con su afán de veracidad a la hora de narrar e interpretar los hechos, libre de los eternos peligros del historiador: la adulación, el panegírico y el interés ${ }^{18}$. Se trata, por una parte, de un tópico de los exordios de la historiografía, pero cobra un nuevo valor al ser Quevedo testigo de algunos de los hechos narrados. Destaca así en este inicio el recurso al testimonio de vista como prueba inartística que refuerza el valor del escrito ${ }^{19}$. Ello no implica, por supuesto, que ese Quevedo testigo no oriente los hechos que relata en beneficio de su posición política.

La segunda dedicatoria, "Al que leyere», subraya el hecho de escribir entre dos reinados. Por ello se organiza como una comparación entre Felipe III y Felipe IV, claramente laudatoria hacia el nuevo monarca

17. Ya lo advirtieron Roncero, 1988, pp. 101-102 y Peraita, 1997, pp. 158-160 y 161-164.

18. Peligros que había ya señalado Luciano de Samosata en Cómo debe escribirse la historia, obra de la que cito dos pasajes significativos: “Para empezar, veamos qué falta tan grande cometen cuando la mayoría de ellos omiten el relato de los acontecimientos y se pasan el tiempo elogiando a gobernantes y generales, elevando hasta el cielo a los suyos y difamando a los enemigos más de lo tolerable; ignoran que la línea que divide la historia y el panegírico no es un istmo estrecho, sino que hay una gran muralla entre ellos y esto es como lo de los músicos: hay un doble diapasón entre ellos; mientras que la única preocupación del encomiasta es elogiar y agradar por cualquier procedimiento al elogiado, y le importaría poco conseguir su objetivo mintiendo, la historia, en cambio, no podría admitir una mentira» (p. 377); “Así son la mayoría de los historiadores, que miman el presente, sus propios intereses y la utilidad que esperan de la historia» (p. 382). Para el concepto historiográfico de Quevedo, véase Roncero, 1991, pp. 17-113.

19. Como se ha dicho, la declaración de los testigos es una de las más importantes pruebas inartísticas, es decir, aquellas que no necesitaban del arte retórica para construirse pues venían dadas por el asunto. Su valor era muy elevado, ya que estaban libres de la manipulación del orador. Véanse Aristóteles (Retórica, 1, 2, 2); Quintiliano (Institutio Oratoria, 5, 1, 1). En relación con Grandes anales y la óptica quevediana que lo presenta como testigo, véanse Peraita, 1997, pp. 165-167 y 172-185, y Ettinghausen, 1997, p. 89. 
y con evidentes recelos de la labor de su padre ${ }^{20}$. La sentenciosidad y la simetría, rasgos presentes en toda la obra, refuerzan dicha contraposición y comienzan a mostrar la importancia de los recursos de estilo para la eficaz transmisión de las ideas políticas. La amplificación por enumeración y anáfora aparece en algún párrafo que pondera las virtudes del nuevo monarca; será un rasgo no demasiado habitual en Grandes anales, texto más orientado a la censura y la advertencia. Una efizaz commutatio resume la contrapuesta visión que ambos monarcas despertaban a Quevedo ${ }^{21}$ :

Yo escribo en el fin de una vida y en el principio de otra; de un monarca que acabó de ser rey antes de empezar a reinar y de otro que empezó a reinar antes de ser rey (Grandes anales de quince días, p. 59)

La narración de los hechos históricos más relevantes a juicio de Quevedo constituye el grueso de la obra. En general avanza respetando el orden cronológico, aunque existen algunos saltos que es necesario valorar: lejos de constituir descuidos o desajustes, suponen un interesante manejo del ordo artificialis para, remontándose a sucesos anteriores, explicar las razones que han motivado aquellos que se dispone a relatar. Así sucede con la recreación de una anterior entrevista de Quevedo con Uceda, que se inserta en el presente de los hechos narrados porque precipitó el final de su carrera política, aspecto que está tratando Quevedo en la línea presente del relato ${ }^{22}$. A estos pasajes narrativos se añaden los juicios y reflexiones de Quevedo. El texto se configura así como una combinación de relato histórico y reflexión político-moral, característica habitual en este tipo de obras quevedianas ${ }^{23}$.

Un recurso, ya mencionado en los preliminares, preside la argumentación del relato: el punto de vista del narrador como un testigo a fin de subrayar su objetividad en los hechos narrados y los juicios vertidos

20. Quintiliano (Institutio Oratoria, 2, 4, 20-21) incluía la comparación entre dos personajes dentro del ejercicio de alabanza y vituperio: "Inde paulatim ad maiora tendere incipiet, laudare claros uiros et uituperare improbos: quod non simplicis utilitatis opus est. Namque et ingenium exercetur multiplici uariaque materia et animus contemplatione recti prauique formatur, et multa inde cognitio rerum uenit exemplisque, quae sunt in omne genere causarum potentissima, iam tum instruit cum res poscet usurum. Hinc illa quoque exercitatio subit comparationis, uter melior uterue deterior: quae quamquam uersatur in ratione simili, tamen et duplicat materiam et uirtutum uitiorumque non tantum naturam sed etiam modum tractat. Verum de ordine laudis contraque, quoniam tertia haec rhetorices pars est, praecipiemus suo tempores.

21. Para este contraste entre la figura de ambos monarcas, véase Jauralde, 1998, pp. 443-445.

22. Sobre estas cuestiones, véanse Roncero, 1988, pp. 101, 198 y 207-208, y Rey, 2005, p. XXVIII.

23. Es también una característica frecuente en la historiografía de cierto fuste; Schwartz, 2007, p. 168, lo ha señalado para el género de las Vidas; Roncero, 1988, pp. 82-83, lo relacionó con la influencia de Tácito en Grandes anales. 
sobre ellos ${ }^{24}$. Es un rasgo frecuente en la prosa política de Quevedo, que tiende a aprovechar su experiencia en Italia para avalar las posiciones políticas que defiende en sus escritos ${ }^{25}$. Vinculado a este enfoque se halla un destacado recurso de la obra: la inserción en el relato de varios discursos y parlamentos pronunciados por diversos personajes protagonistas de los acontecimientos. Es este un antiguo recurso de la historiografía usado, entre otros, por Tucídides o Tácito ${ }^{26}$, y que entronca con las posibilidades que el historiador tiene para cubrir con su inventiva la falta de documentación o para amplificar aquella de la que dispone ${ }^{27}$. Retóricamente se acerca a la sermocinatio, una de las posibles realizaciones de la evidentia o enárgeia: la cualidad del estilo destinada a poner los hechos delante de los ojos. También se estudiaba en el ejercicio retórico de la etopeya, como recogen Hermógenes y Aftonio. En muchos casos, estos parlamentos se concentran en momentos de emotividad y dramatismo, con los personajes que los pronuncian en situación cercana a la muerte: dejar oír su propia voz acrecienta aún más esos afectos que ya mueve la propia situación ${ }^{28}$. El laconismo de esos parlamentos -rasgo común a toda la obra y del que se hablará más a propósito de Mundo caduco - contribuye a reforzar su solemnidad y, con ello, su eficacia. No en vano la sentenciosidad en los discursos de personajes era un rasgo recomendado por los preceptistas del género historiográfico, como Luis Cabrera de Córdoba en su De historia para entenderla y escribirla $(1611)^{29}$.

Otro condicionamiento general de la obra, no alejado de la cercanía de Quevedo a los hechos, es su delicada posición política en los momentos del cambio de reinado, donde su participación en las actuaciones de Osuna en Italia era objeto de investigación. Quevedo intenta mantener su integridad como juez imparcial de la historia y sus protagonistas; pero, al mismo tiempo, debe defender su persona de la implicación en

24. Peraita, 1997, pp. 182-185, señala que esta óptica reforzaría también la defensa que de sí mismo hace Quevedo en lo referente a su participación en la política de Osuna.

25. Aparece también en Lince de Italia y Mundo caduco; Juárez, 2006, pp. 362 y 368 lo ha señalado para esta última obra.

26. Véanse, entre otros, Roncero, 1991, p. 74; Schwartz, 2005, pp. 100 y 2007, p. 169; Nider, 2007, 2010a, 2011, pp. 405-407, y 2013a.

27. No es posible entrar aquí en las fronteras entre historiografía, historia y narración, que subyacen a este y otros procedimientos. Véase el volumen coordinado por Carminati y Nider, 2007, del que se señalarán varios trabajos concretos en estas páginas.

28. Lo subrayó Nider, 2007, p. 269, quien señala este rasgo en Mundo caduco, el Breve compendio de los servicios de don Francisco Gómez de Sandoval, duque de Lerma, y en el discurso que Porcia, mujer de Bruto, pronuncia en la Primera parte de la vida de Marco Bruto. Los discursos incluidos en Grandes anales son: el parlamento de Olivares en el lecho del moribundo Felipe III (p. 62), de Quevedo al duque de Uceda (pp. 80-81), del duque de Lerma en su lecho de muerte (pp. 86-87), de fray Pedro de la Concepción, su confesor, a Rodrigo Calderón en los días previos a su ejecución (p. 97), de Rodrigo Calderón a su confesor en esa misma fecha (p. 98).

29. Ya lo señalaron Nider, 2007, p. 255; Nider, 2011, pp. 405-406, y Roncero, 2014, p. 173. Civil, 1998, p. 370, destacó la solemnidad retórica que atrae con fuerza la atención en los discursos que Mártir Rizo incluye en sus Vidas. 
algunos de los hechos relatados, y también ha de contrapesar los riesgos que pudiera acarrear el manifestar abiertamente algunas opiniones. Conciliar esas posturas no resulta sencillo, y Quevedo echará mano de diversas estrategias argumentativas para ello.

Una de ellas consiste en utilizar la imprecisa y socorrida voz del vulgo para introducir diversas versiones sobre un hecho o para adjudicarle juicios sobre asuntos delicados; Quevedo logra así difuminar su punto de vista, aspecto crucial cuando se trata de opinar sobre poderosos ${ }^{30}$. La estrategia tiene alguna semejanza con la técnica de la remotio, consistente en justificar una acusación descargando la culpabilidad en terceros (Cicerón, De inventione, 2, 29, 86).

Otra estrategia es la empleada en relación con el duque de Osuna. Carmen Peraita (1997, pp. 200-209) ha analizado la difícil argumentación que Quevedo debe construir en el caso de la prisión de Osuna para, sin oponerse abiertamente a quien fue su protector, tampoco contradecir la decisión de su encarcelamiento. Pablo Jauralde (1998, pp. 435-441) también ha señalado las (piruetas» literarias que el escritor debió llevar a cabo en tan comprometida situación. La habilidad argumentativa resulta de vital importancia en un caso en el que el propio Quevedo estaba implicado como asistente de Osuna en Italia. Peraita (1997, p. 204) caracterizó certeramente ese razonamiento como paradójico, pues intenta por un lado anular o soslayar la culpabilidad del duque sin por ello desaprobar su condena y prisión. No es extraña la paradoja en este caso, pues la defensa de Osuna se antojaba difícil en el contexto político de influencias que dominaba la corte. Es lo que retóricamente se llamaría una causa admirabile, es decir, aquella en la que la defensa choca con el sentimiento dominante. La paradoja se vinculaba originariamente a ese contexto $^{31}$. A él pertenecía también un recurso frecuente en los exordios que creo se emplea también aquí: la insinuatio, que, mediante el rodeo y el disimulo desvía la atención del oyente o lector, apartándola de los aspectos que resultan de más difícil justificación y dirigiéndola hacia aquellos más favorables ${ }^{32}$. Para ello resulta fundamental la selección de los hechos que van a referirse. Quevedo pasa por alto la causa de la prisión de Osuna y no menciona qué cargos se le imputaban. Sí se detendrá en otros más favorables y menos comprometedores, como las intrigas de sus enemigos y la lucha entre facciones de la corte. Esta ma-

30. Es un recurso ya estudiado por Roncero, 1988, p. 202, y Peraita, 1997, pp. 190-195.

31. El origen de la paradoja se encuentra en los grados de defendibilidad de una causa: cuando esta defensa chocaba contra el común sentimiento del público o de los jueces se denominaba genus admirabile. Aristóteles la caracterizó en un ámbito más general como aquello contrario a lo que se espera o a la opinión establecida. Sobre la caracterización retórica de la paradoja, véase Margolin, 1988. Peraita, 1994, ha estudiado su importancia en Grandes anales, y Roig Miranda, 1980, en el Marco Bruto. Con carácter general a la prosa de Quevedo, véase Azaustre, 1996.

32. Cicerón (De inventione, 1, 15, 20 y ss.) señala las diversas posibilidades de la insinuatio. 
nipulación argumentativa de los hechos relatados es una característica que se observará también en Mundo caduco.

Que el esqueleto de la obra sea eminentemente narrativo tiene varias repercusiones. Una de ellas es que no abundan los pasajes basados en las probationes argumentativas. Estos recursos, muy frecuentes en memoriales y tratados quevedianos, no lo son tanto en Grandes anales, pues el predominio de la narración impone otros cauces para transmitir con eficacia los presupuestos políticos. Una excepción la constituye la extensa reflexión sobre la no conveniencia de situar religiosos en los cargos de gobierno, que censura su proliferación bajo el reinado de Felipe III y, al tiempo, alaba su disminución en los inicios del de Felipe IV (Grandes anales, pp. 74-78). Se concentran allí pruebas retóricas como las citas de autoridades, los praeiudicia ${ }^{33}$, o algunos raciocinios de cierta complejidad. En el primer pasaje de los abajo citados se observa la presencia de praeiudicia junto a la correctio, subtipo de antítesis que subraya la conveniencia de la decisión frente a la opinión negativa que pudiera despertar. En el segundo ejemplo, un extenso razonamiento da cabida a la comparación antitética que diferencia el oficio del religioso y el del consejero de estado, y a una concessio $^{34}$ que, aun admitiendo el valor del estudio y la sabiduría que caracterizan a los religiosos, pone por encima de ellos su falta de experiencia en cuestiones mundanas y una cierta debilidad a la hora de tomar decisiones, debida a la obediencia divina ${ }^{35}$ :

Hemos dicho cuán grande ha sido el celo de esta obra y ponderado la manera de ejecutarla, pues ni los despidió ni los dejó, antes los desengañó y los tornó a encaminar; y fue, como he dicho, restitución de almas y conciencias, y no deposición de personas. Ahora diré que su majestad lo debía hacer así y lo debe continuar por orden de los sacrosantos concilios que así lo ordenan, sin mitigar la nota ni las palabras con ninguna dignidad eclesiástica. Léense en el Concilio de los Apóstoles tales palabras, canon 7: Episcopus, aut Presbiter, aut Diaconus nequaquam seculares curas assumant: sim aliter, dejiciantur. Y el canon 7 del Concilio Calcedonense; y Gelasio papa, en su Decreto, cap. 15. Leyendo en el Concilio Africano, canon 71: Placuit, ut quicumque ab imperatore cognitionem iudiciorum publicorum petierit, honore proprio privetur (Grandes anales de quince días, pp. 75-76)

33. Una sentencia judicial o ley promulgadas con anterioridad sobre el mismo asunto que se está tratando o sobre uno muy similar; véase Quintiliano (Institutio Oratoria, 5, 2) para sus diferentes tipos y rasgos.

34. Esta figura dialéctica consiste en reconocer que la parte contraria lleva razón en un aspecto, para a continuación matizar que ese aspecto es de escasa importancia en comparación con el meollo de la cuestión, donde su postura es incorrecta.

35. Parece clara la alusión a Felipe III al hablar de esa debilidad causada por la extrema devoción y piedad religiosas. Una interpretación de la sumisión de los cargos eclesiásticos a la jurisdicción temporal en un contexto histórico y político más amplio ofrece Martínez Millán, 2014, pp. 118-129. Por otra parte, el pasaje encierra una interesante reflexión que reconoce la maldad intrínseca a la razón de estado y la práctica de gobierno y, al mismo tiempo, la valora como necesaria. 
Y pareció que esta caridad que su majestad tiene en quitar las ocasiones de divertimento con ocupaciones seculares a los religiosos debía extenderse a no proseguir en hacer consejeros de Estado a los confesores, porque no hay cosa más diferente que estado y conciencia, ni más profana que la razón de estado $[\ldots]$.

Decir que tiene dependencia la confesión y el consejo de estado no es cosa platicable, pues lo uno se gobierna por sumas, y lo otro, por aforismos y leyes y conveniencias; lo uno quiere doctores, lo otro pide experimentados; aquella, profesión es de teólogos, ésta, de prevenidos y astutos. Y cuando fuera así que la lección y los estudios arribaran a esta cumbre, ¿qué noticia que no sea pobre, qué experiencia que no sea mendigada de la relación podrá tener un religioso, si ya no presumiesen de monarcas los superiores y nos quisiesen contar los conventos por provincias? Antes es cierto que el escrúpulo y el encogimiento de la observancia y el abatimiento victorioso para con Dios de la obediencia divina apocan el orgullo de las proposiciones políticas y la lozanía de las malicias del gobierno (Grandes anales de quince días, pp. 76-77).

Salvando algún ejemplo como los anteriores sobre los religiosos, los pasajes de carácter argumentativo son las ya mencionadas apostillas engastadas en el armazón narrativo del discurso. Para no convertirse en digresiones, dichos comentarios se integran de manera fluida en el relato histórico. Con frecuencia se resuelven en una breve oración de relativo, bimembre y simétrica en su sintaxis, especialmente cuando encierran una opinión que sintetiza la vida de un personaje:

Murió luego Antonio de Aróstegui, secretario de Estado, que debió mucho crédito a su silencio y mucha estimación a su reposo (Grandes anales de quince días, p. 109) ${ }^{36}$.

Esta alternancia de narración y comentario provoca que la estrategia argumentativa privilegie sobre las tradicionales pruebas (signa, argumenta y exempla) lo que podríamos denominar el uso argumentativo de los recursos de estilo, orientados aquí no solo al embellecimiento literario sino, a través de él, a la persuasión.

Preside a todos ellos la sentenciosidad, rasgo que sobresale no solo en los juicios morales y políticos sino incluso en los pasajes narrativos, donde el habitual período amplio de la narración histórica -peribolé,

36. Collado Ruiz, 2014, pp. 183-184, interpreta este juicio de Quevedo sobre Antonio de Aróstegui como una ponderación de «su labor callada y fiel durante años», y señala (pp. 180 y 182) el hecho de que le fue concedido el hábito de la Orden de Santiago, algo que también indica Roncero (en Mundo Caduco, p. 109, nota 162). Debe tenerse también en cuenta que la brevitas y la agudeza de Quevedo pueden esconder en ocasiones una deliberada oscuridad -cuando no ambigüedad- en la lectura de estos pasajes; véase Llamas Martínez, 2016, pp. 198, 204 y 219-220. Quevedo mencionó al secretario del rey en su romance “Cansado estoy de la corte» (vv. 61-64): «Ver arremedar privanzas / un hablador y un malsín, / encajando el "Despachamos", / y un poco de Arosteguí». Véase también Jauralde, 1998 , p. 466 , nota 25. 
según lo denominaba fray Luis de Granada en su Retórica eclesiástica-, con su encadenamiento sintáctico de detalles y circunstancias, cede a menudo ante un laconismo más propio del tratado moral ${ }^{37}$. La brevedad sintáctica convertirá estos pasajes en sucesiones de sentencias que transcriben de manera solemne el juicio de Quevedo. Incluso cuando se utiliza un razonamiento en período circular, su brevedad y frecuente cierre lacónico y simétrico lo incorpora a esa brevitas que preside el discurso. Ese laconismo sintáctico ve reforzada su fuerza expresiva por su frecuente combinación con el paralelismo, rasgo de estilo muy frecuente en la prosa política y moral de Quevedo ${ }^{38}$.

La fuerza expresiva de esta sintaxis sentenciosa es un rasgo reconocido en la retórica, donde se le atribuye la cualidad de la solemnidad que, vinculada a la sententia, la hace muy adecuada para las advertencias morales ${ }^{39}$. Resulta lógica, pues, su presencia en estos pasajes de Grandes anales que acompañan el recorrido por la historia de advertencias políticas y morales.

En el marco de esa simetría sentenciosa, son varios los recursos que Quevedo utiliza para argumentar a favor de sus ideas. Muy destacado es el ámbito de la antítesis que, en su conocida función de oponer las malas y buenas conductas, se revela aquí de gran utilidad al estar valorándose un período de cambio entre dos reinados ${ }^{40}$. Muy frecuente es el uso de su modalidad cruzada o commutatio, y también de la correctio. Esta última tiene una finalidad claramente amplificadora, pues, en lugar de mencionar directamente una acción o un calificativo, acentúa su carácter positivo o negativo oponiéndolo a la negación de su contrario ${ }^{41}$. $\mathrm{Su}$ abundancia en Grandes anales revela un rasgo muy destacado en la intención de la prosa política y moral de Quevedo - y, en general, en su perfil de escritor-: su gusto por la sátira, por la censura de costumbres y comportamientos, que aparece en estas correctiones como contrapunto incluso de las conductas que se alaban en Felipe II y Felipe IV ${ }^{42}$. Señalo algunos ejemplos:

[Correctio para subrayar la alabanza de Felipe IV]

Hemos dicho cuán grande ha sido el celo de esta obra [restitución del patronato único a Santiago apóstol] y ponderado la manera de ejecutarla, pues

37. Lo advirtió Rey, 2005, p. xxxix.

38. Azaustre, 1996.

39. De hecho, la sententia puede considerarse una prueba retórica que opera por inclusión, pues la afirmación de carácter general engloba la tesis concreta que se quiere defender; véase Azaustre y Casas, 2015, p. 139.

40. Ettinghausen, 1998, p. 155, señaló acertadamente esa importancia de la estructura sintáctica y la antítesis en Grandes anales: «Quevedo busca efectos retóricos, más que por el uso de metáforas, por la manipulación de estructuras sintácticas, en especial la antítesis». Su trabajo recoge diversos ejemplos de este uso de la sintaxis y la antítesis como recursos orientados a la persuasión política.

41. Rhetorica ad Herennium $(4,26,36)$.

42. Lo señalaron Ettinghausen, 1997, pp. 92-97, y Rey, 2005, p. xxxvıII. 
ni los despidió ni los dejó, antes los desengañó y los tornó a encaminar; y fue, como he dicho, restitución de almas y conciencias, y no deposición de personas (Grandes anales de quince días, pp. 75-76).

[Correctio en alabanza de Felipe II y posible censura a la debilidad de Felipe III]

[Felipe II] fue espléndido y magnífico, como lo han de ser los reyes, no como quieren que sean los codiciosos: daba y no vertía; premiaba méritos, no hartaba codicias. La condición tratable, no ocasionada a la familiaridad (Grandes anales de quince días, p. 111).

[Correctio sobre el correcto papel del valido] ${ }^{43}$

Con la indiferencia referida caminaban las cosas, de manera que se asegura que los validos sirven a su majestad y no le violentan, porque en tan tiernos años ama el trabajo de suerte que quiere bien a quien le ayuda, no a quien le descansa y descuida; que no quiere privados que le ocasionen el ocio, sino que le acompañen en el trabajo; que le sigan y no le arrastren; que le acudan y no le compitan (Grandes anales de quince días, p. 68).

[Correctio y rectas intenciones de Felipe IV en relación con el peligro de los malos consejeros]

Quiere ser obedecido y no violentado; busca no sólo el consejo, sino suficiencia del que se le diere (Grandes anales de quince días, p. 112).

La sorpresa de la paradoja es un rasgo muy aprovechado por Quevedo en su prosa política y moral. Combinada con la sentenciosidad o la simetría, transmite con eficacia lapidaria la virtud neoestoica que considera un logro el carecer de dignidades (p. 88) ${ }^{44}$, o el oscuro panorama de una corte donde la disimulación cautelosa anida bajo el afable rostro de consejeros y aduladores (p. 80). Otras apariciones de la paradoja tienen intenciones más concretas, vinculadas al devenir de diversos personajes históricos. Así, subrayan cómo las propias obras de fray Luis de Aliaga fueron su castigo (p. 83), o la caída de Rodrigo Calderón, tan admirado en su muerte como denostado en vida, constituyó su mayor logro (p. 96 ${ }^{45}$. En un tono menos trágico pero no menos punzante, se retrata la excesiva dadivosidad de un Lerma que “fue sabroso hasta en no favorecer» (p. 86). En el último ejemplo citado abajo, la paradoja muestra cómo la codicia pervierte la tradicional virtud neoestoica que considera un logro el carecer de dignidades, pues a Francisco de Contreras, una primera negativa de Felipe III a su pretensión de presidir el Consejo Real le llevó a retirarse al cuidado de los

43. Ettinghausen, 1998, p. 156, señaló este pasaje como ejemplo del contraste entre las medidas del nuevo gobierno y las del anterior.

44. Para esta faceta del pensamiento de Quevedo, véanse los clásicos trabajos de Blüher, 1983, y Ettinghausen, 2009.

45. Ettinghausen, 1998, p. 160, señaló la serie de paradojas que se reunían en el retrato de su ejecución. 
hospitales de Madrid, retiro desde el que fue requerido por Felipe IV para ese cargo (p. 88) ${ }^{46}$ :

Y estas cosas, señor, disimulan en las lisonjas amenazas, y los que celebran la correspondencia y amistad de vuecelencia, en el aplauso de hoy cubren la calumnia de mañana (Grandes anales de quince días, p. 80).

su confesor, pasándole a serlo por él del rey, dejó de ser su absolución y fue su penitencia (Grandes anales de quince días, p. 83).

La muerte de don Rodrigo Calderón fue lo que vivió, y su vida es su muerte. Oíd la historia de dos hombres en una vida y atended la historia del privado que nació de su ruina: veréis uno que se edifica con su caída (Grandes anales de quince días, p. 96).

Diose la presidencia a Francisco de Contreras, del Consejo Real, a quien la ambición de la cámara que le negaron retiró a cuidar de los hospitales: nueva invención de codicia, dejar para adquirir. Aceptó la presidencia y desdíjose de la mortificación y, desertor del retiramiento, descifró el asunto de la recolección. A este sujeto vino a retraer la presidencia ya casi delincuente (Grandes anales de quince días, p. 88).

Sintácticamente reducido al sintagma, pero con la misma finalidad de sorprender por lo ilógico, encontramos el oxímoron, ya comentado a propósito del título de la obra. Otro ejemplo lo constituye el que cierra el lamentable final del presidente de Castilla, don Fernando de Acevedo, obligado a retirarse a la iglesia de Burgos, donde «yace vivo» ( p. 89).

También en la esfera de la antítesis puede situarse el dilemma ${ }^{47}$. Por las razones antes apuntadas, en Grandes anales no adquiere el protagonismo que se observa en los memoriales y tratados de Quevedo, pero asoma para mostrar el callejón sin salida que se presenta a Olivares en la delicada cuestión de las sucesiones futuras. El pasaje guarda una gran similitud con el que retratará la ingratitud que rodea a los privados en Virtud militante:

Sea el primer artículo el desempeño justo y forzoso. Empezádose ha a tratar, y sólo de los amagos de él se lamentan y capitulan por los corrillos a los que no lo ejecutan. Si se tratan, se quejan y llaman tiranos a los que lo proponen, y a los medios desolación; si no se practica, dan voces y llaman ladrones a los que lo dejan perdido como a los que lo perdieron, teniendo éstos que lo padecen la pena de los que tuvieron la culpa y lo disiparon.

El primer ministro que se ha atrevido a no temer este peligro forzoso, llevado de lo magnífico de estas promesas tan aventuradas, ha sido el conde de Olivares, pues animosamente, si no arriesga su puesto, lo embaraza con desabrimientos populares, dificultades de ministros, contradicciones de

46. Jauralde, 1998, p 448, señala cómo «Quevedo maltrata con su estilo al nuevo Presidente de Castilla, Francisco de Contreras». Ettinghausen, 1998, pp. 158-159, subrayó las «delicias del ingenio» que reunía este pasaje con intención satírica.

47. Exposición de dos razones contrarias que llevan a un mismo resultado. 
curiosos y advertencias de entremetidos, a quien mejor llamar parlerías desocupadas, que en todo tiempo hicieron oficio de cizaña a grandes motivos.

Todos dicen: «desempéñese el rey». Uno solo lo trata, y se ha de hacer con todos; y ellos al efectuarlo quieren que se haga para todos y con ninguno. Si se trata de imposición, se espantan los pobres y los oficiales; si de erario, se retiran los ricos mal satisfechos; con decir: "todo es de nuestro rey y para su servicio", muestran fidelidad aparente y lealtad interesada. Crecen las dificultades, empeñan el celo del ministro que trata del desempeño y quieren hacer que pasen contradicciones por servicios y promesas por obras (Grandes anales de quince días, pp. 105-106).

Los privados de los reyes pasan sin saber qué es agradecimiento porque, aunque den a todos lo que piden, ninguno dice que recibió lo que merece. Si da a todos, dicen todos que los iguala, y que con eso los afrenta; si da a pocos, dicen los mismos que lo hizo a más no poder. Si tarda en el despacho, que se le hizo desear, y desfalcan del beneficio los pasos y las palabras; si abrevia el decreto, que por no verlos ni oírlos. Si hace merced a sus parientes y criados, que es codicioso, que sólo es mérito ser su deudo, que ser de su sangre es sólo suficiencia; si no los favorece ni ayuda, que es demonio, que quien no honra a sus deudos, ¿cómo honrará a los que no lo son? Si recibe, dicen que es ladrón; si no recibe, que es mejor venderlo bien que darlo mal. Si asiste siempre a su rey, dicen que le cerca y le teme; si no le asiste, que le desprecia. Ella es una dignidad esclava del trabajo, combatida de la invidia, cercada del aborrecimiento, que siempre vive en peligro, que sube por asperezas trepando, que baja resbalada por hielos, que nadie la ve subir que no la aguarde caer, que nadie la ve caída en tan profunda sima que no se la ahonde para que siempre caiga (Virtud militante, pp. 501-502).

Capítulo especial en el uso argumentativo del estilo merece la metáfora. La agudeza quevediana la traslada aquí del terreno ornamental del delectare al más hiriente de la censura política, que subraya mediante una expresión gráfica e intensa ${ }^{48}$ propiciada por la ingeniosidad de la analogía ${ }^{49}$. De esta forma, lo inconveniente de que los religiosos ocupen cargos políticos - algo frecuente con Felipe III- se resuelve con una combinación de metáforas que los transforma de médicos en enfermedad del alma del rey (p. 77). El discurso que el carmelita Pedro de la Concepción dirige a Rodrigo Calderón la víspera de su muerte contiene una sucesión de metáforas que resumen su vida de forma gráfica: recu-

48. Afirma Lausberg, 1984, § 558: «debido a la brevitas la metáfora es más oscura pero también más inmediata e incisiva que la comparación».

49. Lo advirtió Rey, 2005, p. XLI. La finalidad de la metáfora para transmitir con más fuerza y viveza es generalmente considerada en los tratados retóricos; así en Quintiliano (Institutio Oratoria, 8, 6, 5-6). Para el papel de la metáfora en la argumentación moral, política y religiosa, véanse Redondo, 1992; Étienvre, 1998. En relación con la obra política de Quevedo, ver, por ejemplo, Juárez, 1990, pp. 193-197; Riandière La Roche; 1992; Vaíllo, 1998. En relación con la intención satírica en la obra de Quevedo, véase el análisis y caracterización de Schwartz, 1984. Desde el enfoque de la nueva retórica también se destaca su importancia en la argumentación; véase Perelman, 1994, pp. 610-626. 
rriendo a la tópica identificación con la escritura ${ }^{50}$, afirma que «su vida es el libro más docto que el tiempo y la fortuna compusieron» y «cada día es una hoja donde se leen con alma los desengaños» (p. 97) ${ }^{51}$. A esta lección a contrario se une la idea -ya empleada con Aliaga y otros personajes de la corte- de que él mismo fue el causante de su ruina, al retratarlo como (un jornalero de su penitencia» y (un asalariado de su ambición» (p. 97).

La metáfora intensifica también diversos rasgos negativos en los retratos de ministros que cierran Grandes anales. El duque de Lerma fue “posesión del marqués de Siete Iglesias y de otros muchos» (p. 113) y, en hábil combinación con la paradoja, se afirma que cfue su familia su delito» (p. 113). La ambición del duque de Uceda lo convierte en «tropezón de la dicha de su padre» (p. 114).

La agudeza mediante diversas figuras que juegan con los vocablos resulta también apreciable como instrumento para la sátira política ${ }^{52}$. Así, la paronomasia subraya las veladas acusaciones que, apoyadas en la salvaguarda de la rumorología popular, apuntaban a Rodrigo Calderón como instigador de la muerte de doña Margarita de Austria («de su fin tenían más culpa los malos que los males», p. 91); en parecida línea, políptoton y silepsis acentúan el negativo perfil de este personaje, quien, al calificar el legado que dejó a su familia al morir, afirmó que «lo mejor que les dejo es dejarlos» (p. 98). Por último, los peligros que acarrea la proliferación de oficios en dote se subrayan mediante un expresivo cierre en políptoton que coquetea con la antítesis: "pero esto tiene de bueno este mal uso, que o brevemente se acabará, o nos acabará a nosotros» (p. 107).

Como se ha podido observar, la censura política predomina sobre la alabanza, bastante poco frecuente en Grandes anales ${ }^{53}$. Solo algunos pasajes emplean los típicos recursos de la laudatio -amplificación enumerativa o congeries, figuras de reiteración y entonación...- en alabanzas que se concentran en las figuras de Felipe IV y, algo menos, en Olivares. El talante satírico y censor de Quevedo, rasgo esencial en su pensamiento y escritura, se aprecia con claridad en Grandes anales, cuyo recorrido histórico se ve jalonado por advertencias dirigidas al gobierno de Felipe IV a fin de no perpetuar males anteriores ${ }^{54}$.

50. Curtius, 1981, pp. 423-489, señaló ejemplos de las metáforas del libro y la escritura en el capítulo «El libro como símbolo».

51. Jauralde, 1998 , p. 449, ha subrayado la fuerza de estos parlamentos directos del confesor y del propio Rodrigo Calderón.

52. Su importancia y finalidades en la prosa satírica de Quevedo fueron estudiadas por Schwartz, 1986, pp. 19-45; Arellano, 2003, pp. 299-313, lo hizo en su poesía satíricoburlesca.

53. Lo señaló Ettinghausen, 1997, pp. 92-97.

54. Incluso cuando Quevedo parece negar una censura política por resultar indecorosa o excesiva, el pasaje deja entrever cierta ironía que apunta hacia la crítica. Así sucede con los rumores que achacaban a Rodrigo Calderón la muerte de doña Margarita de Austria (p. 91), o que imputaban al gobierno de Felipe III el exceso de oficios en dote (p. 107). 
La sección final de la obra la constituye una breve galería de retratos de reyes y ministros que ilustran la anterior crónica $^{55}$. Como sucedía en la narración, también el marco del retrato le sirve a Quevedo para insertar sus juicios morales y políticos ${ }^{56}$. Se inscribe así en una vertiente psicologista de la historiografía común desde el Renacimiento y con evidentes ecos en la obra de Tácito ${ }^{57}$. Los retratos de Grandes anales siguen un esquema general común, que comienza por los rasgos físicos y facciones para avanzar desde ellos a los psíquicos y a su comportamiento y obras. Ya en el tratamiento de las facciones se señala su implicación psíquica, aspecto que habrá de analizarse en detalle en otro lugar, pues conoce una rica tradición. El laconismo y la simetría se reiteran en esta sección, y recursos como la comparación, la antítesis y la correctio se adecuan bien a una argumentación que pretende persuadir por su solemnidad expresiva. También en ellos debe destacarse la importancia de la metáfora, cuya agudeza se orienta a la censura del personaje.

En conclusión, Grandes anales de quince días es una obra cuya tesis política -esperanza en el nuevo gobierno de Felipe IV y Olivares y advertencia sobre errores anteriores- se transmite en breves y lacónicos juicios fluidamente integrados en el discurso del relato histórico, el cual se apoya en el aval de una interesada perspectiva de testigo. La fuerza de ese laconismo da cabida en su sintaxis a un persuasivo empleo de comparaciones y antítesis, cuando no de agudas metáforas y juegos de palabras. Sentenciosidad y agudeza, rasgos literarios fundamentales en la prosa de Quevedo, aplican aquí su valor expresivo a la eficaz transmisión de un pensamiento político marcado por la advertencia y la sátira. Ello provoca que tropos y figuras orienten su finalidad ornamental hacia la crítica, retomando una de las dos grandes vías -alabanza y vituperioque la retórica les tenía reservadas en el seno del género epidíctico.

\section{Mundo caduco y desvaríos de la edad}

Escrita entre 1621 y 1623, constituye un relato histórico de la delicada situación europea entre 1613 y $1620^{58}$. Se organiza en cuatro capítulos, cada uno de los cuales relata sucesos acaecidos en distintos escenarios. Como se verá más adelante, la disposición de los tres primeros capítulos responde a una sucesión lógica, aunque existen algunas discrepancias sobre la ubicación del que suele considerarse cuarto

\footnotetext{
La ironía es también eficaz cauce para censurar a los monarcas alabándolos de lo que no tienen u obran, como mostró Quevedo en el Discurso de las privanzas y Virtud militante.

55. Jauralde, 1998, pp. 441-448, ha detallado las circunstancias históricas que rodeaban a los personajes retratados.

56. Rey, 2005, p. XxxviII.

57. Sobre el carácter psicológico de la historiografía y la influencia de Tácito a propósito de Grandes anales, véase Roncero, 1988, pp. 76-79.

58. Roncero, en Quevedo, Mundo caduco, pp. 119-120.
} 
( Valtelina») $)^{59}$. Este hecho y su peculiar transmisión manuscrita, vinculada a los Grandes anales, hace pensar que nos hallamos ante una obra inconclusa que pudiera formar parte de un proyecto inacabado de mayor envergadura junto a aquella obra ${ }^{60}$. Es un rasgo que se reitera en los escritos históricos y políticos de Quevedo.

El primer capítulo (“Venecia y los uscoques») relata las diferentes luchas acaecidas entre venecianos y uscoques, aliados coyunturales de los Habsburgo cuya presencia en la obra de Quevedo y en otros textos venecianos y españoles de la época ha sido rigurosamente estudiada por la crítica $^{61}$. El relato está claramente orientado a dibujar a los venecianos como instigadores de conflictos en Europa y enemigos de la corona española, una línea que Quevedo repetirá en otros escritos políticos. Al tiempo, su postura constituye una defensa de la política militar de Osuna contra ellos, como muestra el pasaje que cierra la sección (pp. 152-154). El segundo capítulo («Bohemia») enlaza con el anterior, pues Venecia se presenta como instigadora de las revueltas que dieron lugar a la Guerra de los Treinta Años. Este capítulo relata la fase del conflicto protagonizada por los bohemios, y se centra en los avatares sufridos por el conde Palatino hasta su derrota frente al duque de Baviera ${ }^{62}$. El tercer capítulo ( Don Gonzalo de Córdoba») también enlaza de manera coherente con el que le precede, pues se inicia retomando la figura del conde Palatino tras la derrota con la que finaliza la sección anterior. La figura de don Gonzalo de Córdoba entra en escena para aplacar al conde Arnesto de Mansfelt, uno de los aliados que el conde Palatino buscó tras su derrota. El grueso del capítulo se detiene en relatar la victoria de don Gonzalo sobre Mansfelt. El capítulo final (“Valtelina») constituye un relato de la campaña del duque de Feria - gobernador de Milán en 1618- en este tránsito desde el norte de Italia al centro de Europa.

Como en el caso de Grandes anales, al ser Mundo caduco una obra eminentemente narrativa, no abundan los pasajes construidos sobre las pruebas de argumentación retórica. Su finalidad fundamental se centra en narrar los hechos históricos, bien con la fluidez del estilo suelto, bien en amplios períodos cuando se acumulen detalles de los sucesos. No obstante, la selección de los episodios narrados, los retoques interesados en la cronología y la manipulación de las fuentes en favor de su posición política son rasgos de la escritura quevediana que, junto al uso del estilo para mover al destinatario, suponen una orientación ar-

59. Biurrun en Quevedo, Mundo caduco, pp. 24-33 y 47-48, lo considera el primero; Roncero, Quevedo, Mundo caduco, pp. 125-126, el cuarto de un proyecto inacabado junto a Grandes anales.

60. Así lo cree Roncero, en Quevedo, Mundo caduco, p. 126; para Biurrun, en Quevedo, Mundo caduco, p. 15, es una obra con una estructura cerrada y acabada.

61. Véanse, en relación con la obra de Quevedo, Budor, 1995; Juárez, 2006; Nider, 2007, 2010b, 2013a y 2014.

62. Maximiliano I (1573-1651), duque de Baviera. Su victoria frente al conde Palatino tuvo lugar en la batalla de la Montaña Blanca, cerca de Praga, a 8 de noviembre de 1620. 
gumentativa del relato, tal y como ha advertido la crítica $^{63}$. En el fondo de esta actitud se encuentra la frecuente orientación política de la historiografía, las débiles fronteras entre esta y la literatura de corte político $\mathrm{o}$, si se quiere, el eterno problema del historiador -o de quien presenta su escrito como tal-, que ha de ser fiel a la verdad de los hechos pero que inevitablemente se halla inmerso en unas circunstancias que condicionan su posición ante ellos. Quevedo es más un escritor político que un historiador en sentido estricto $y$, en consecuencia, la historia se ve sometida en sus escritos a una manipulación argumentativa que la orienta a sus intereses.

La carga argumentativa de esta obra se centra en dos tipos de pasajes. Por una parte, en los juicios sentenciosos que se integran en la narración ${ }^{64}$. Lo más frecuente es incorporar al relato juicios sobre personajes y hechos mediante correctiones o comparativas que permiten subrayar una característica normalmente negativa, pues de nuevo la censura política es la actitud que predomina:

Este bastardo [Ernesto de Mansfeld] y el obispo de Halberstad, llamado el Luterano, se juntaron para lograr disinios de diversión forzosa, que se destinaron bien y se lograron mal. Y para esto dio intención de concertarse con el rey de Francia. Propuso partidos al duque de Nivers por medio del de Bullon, que mañosamente entretenía los tratados, como persona plática y que siempre ha fiado más de su artificio que de su poder (Mundo caduco, p. 171).

Estos juicios sentenciosos no son tan frecuentes como en Grandes anales, pero pueden encontrarse en todas las secciones de Mundo ca$d u c o^{65}$. Donde más aparecen es en la última de ellas, (Valtelina»; en-

63. Así lo han señalado diversos estudiosos: Budor, 1995, pp. 335-336, recela de su veracidad como documento histórico, y sitúa la obra a medio camino entre el documento histórico, el texto político y la recreación literaria; el trabajo muestra el uso por parte de Quevedo de las fuentes documentales al servicio de su posición política e ideológica, rasgo, por otra parte, común a los escritos que cruzaron los bandos enfrentados. Biurrun, en Quevedo, Mundo caduco, pp. 12-18 y 31-33, no lo considera un documento histórico, sino la exposición de una ideología política y la defensa de Quevedo ante las acusaciones vertidas contra él a su vuelta de Italia. Juárez, 2006, pp. 364-372, subraya la visión partidista de Quevedo favorable a la política de Osuna y, en consecuencia, exaltadora de los uscoques y contraria a Venecia. Roncero, 2014, pp. 162-171, muestra cómo ese concepto historiográfico de Quevedo que, como Tucídides y otros historiadores, prefería centrarse en hechos contemporáneos para ser más fidedigno, convive con su orientación en favor de la política de Osuna, haciendo de su óptica la de un testigo parcial. Nider, 2010b, 2013a, 2014, ha comparado en detalle la obra de Quevedo con otros textos enfocados desde la misma óptica y desde la veneciana, y ha mostrado las diferencias que derivan de sus posiciones políticas.

64. Budor, 1995, p. 344, señaló ese importante papel del estilo en la transmisión de los contenidos de Mundo caduco.

65. Véase, por ejemplo, la sentencia - la marco en cursiva- que extrae un juicio político de diversos hechos en torno a don Gonzalo de Córdoba: «mas, persuadidos de la voz que se derramaba con maña de los conciertos hechos con Francia, se retiraron a sus casas, no sin sospecha y malcontentos; que el discurso de los entendidos forzosamente cede al ímpetu de la multituds (Mundo caduco, p. 172). 
contramos allí estas expresiones lacónicas con diversos fines: censurar a Felipe II su (encogimiento» al no acometer acciones en esa zona ( $p$. 179), criticar a los malos consejeros a propósito de los que asesoraban al conde de Fuentes, gobernador de Milán (pp. 179-180), o subrayar la ingenuidad de los embajadores franceses ante las cautelas de los venecianos (pp. 182-183):

Esta diligencia fue por demás, y al rey, inútil; pues no pudo valerse della, divertido y fatigado con las divisiones de Francia que ya padecía por no haber disimulado bien su intento. Los reyes que anticipan el discurso y emperezan los discursos, ni la verdad los llama sutiles ni los sucesos valientes. No les perdonan el mal nombre los escritores: déjanle pasar a más días donde se aseguren con la distancia (Mundo caduco, p. 179).

Esto le propusieron aquellos ambiciosos del lado del gobernador, que siempre le reciben con novedades sabrosas al que llega, peligrosas al que las trata, aventuradas para el que las prosigue. Con estas cosas desperdician el seso del que empieza y, en el crédito que les da, experimentan su talento de manera que le espían más que le proponen. El conde, que era hombre endurecido de armas y soldado en tanto valor como dicha, por salvarse contra la maña destos [...] (Mundo caduco, pp. 179-180).

Y con ser esta plática [el discurso de los venecianos] tan injuriosa a los príncipes y tan dañosa a los franceses, no lo sintieron, y pasó arrebozada por delante de muchas sospechas suyas sin ser conocidas. Tanto sabe aquel senado y ministros desmentir sus pisadas y desconocer su veneno.

Los embajadores de Francia vieron que asistían esguízaros y estaban confiados que podían a su arbitrio disponer de aquellas gentes. Embajador confiado y gobernador crédulo ahorran trabajo a los enemigos. Con ministro que se asegura y se satisface, poca habilidad muestran los engaños (Mundo caduco, pp. 182-183).

Mayor importancia que estos juicios sentenciosos tiene la incorporación al relato de orationes de diversos personajes. Es un rasgo del que ya se ha hablado a propósito de Grandes anales, y que logra una intensa apariencia de vida y veracidad (evidentia) al tiempo que una fuerte carga expresiva destinada a mover los afectos. Estos discursos encierran buena parte de los recursos de argumentación de Mundo caduco, pues la finalidad de quienes los pronuncian es persuadir a sus oyentes, sobre todo mediante la moción de afectos. Se trata, sobre todo, de arengas militares cuyas implicaciones históricas y políticas han sido estudiadas en detalle por Victoriano Roncero, Encarnación Juárez y Valentina Nider ${ }^{66}$.

Dos discursos de los uscoques aparecen en el primer capítulo. El primero muestra una meditada organización antitética que, como indicó Nider (2007, p. 260), subraya el valor del pequeño pueblo uscoque

66. Roncero, 1991, p. 74; 1994; 2014, pp. 173-177; Juárez, 2006, pp. 366-368; Nider, 2007, pp. 259-265; 2014, p. 153. 
frente a la cobardía y cautelas de la insigne república de Venecia. El segundo es un caso atípico, pues incorpora pasajes de una obra anónima, el Squitinio della libertà veneta ${ }^{67}$. Ello repercute en su organización y desarrollo, que recurre menos al laconismo y se basa en una relación -así la llama el propio Quevedo (p. 147) - de agravios venecianos y derechos de los uscoques, con apoyo en citas de autoridades y leyes, así como en algún ejemplo bíblico ${ }^{68}$. Además de ello, el ser pronunciados por un uscoque, pueblo cuyo valor convivía con la fama de piratas, distancia a Quevedo de su propia opinión, claramente favorable a la política belicista de Osuna y contrario a posturas oficiales menos beligerantes ${ }^{69}$.

En el segundo capítulo («Bohemia») encontramos dos discursos del conde Palatino: el primero dirigido a los bohemios; el segundo, a sus tropas. En ambos casos defiende el nombramiento de emperador mediante elección y no por derecho hereditario, como pretendía España. A esta postura se opone la que enarbola el duque de Baviera en la arenga que dirige a sus tropas. Valentina Nider (2007, pp. 264-265) ha señalado cómo estos discursos contrapuestos entroncan con la práctica del género deliberativo, y cómo Quevedo orienta claramente su construcción a favor de la postura hereditaria, apoyada en la autoridad de la Biblia. Victoriano Roncero (2014, pp. 174-177) ha contrastado el primer discurso del conde Palatino y el del Duque de Baviera, y ha mostrado cómo Quevedo orienta hacia su posición política la presentación de los asuntos en ambos casos.

Desde el punto de vista de la argumentación, las tres orationes mueven mediante la sentenciosidad y simetría de su sintaxis, y son ricas en recursos como la comparación antitética o la correctio, muy útiles en la alabanza y el vituperio. Señalo un pasaje situado al final del primer discurso del conde Palatino; junto al apóstrofe y la vehemente interrogación retórica, la anticipatio que previene el valeroso comportamiento futuro de los bohemios, la simetría, las anáforas y la correctio sostienen la moción de afectos, fundamental en los finales de estas orationes:

¿Cuál de vosotros ha esperado mi determinación para saber esto, que tan aprisa nos va desarrebozando la ruina? Yo, amigos, sólo he repetido vuestras imaginaciones y descerrajado vuestro silencio. No os incito a tomar las armas; que a esa diligencia se me adelantó vuestro cuidado y coraje, que os puso en campaña; ni dudo que proseguiréis por la honra y por la vida lo

67. Así lo ha indicado la crítica: Astrana en Quevedo, Obras, p. 459, nota 1; Budor, 1995, pp. 334-335; Rey, 2005, p. xurv; Roncero en Quevedo, Mundo caduco, p. 140, nota 52; Juárez, 2006, p. 363; Nider, 2007, p. 261; Nider, 2010b, p. 216.

68. Véase la completa información que sobre la tradición retórica de estas orationes ofrece Nider, 2010b, p. 227, notas 23 y 24 . Nider, 2007, p. 261, ya advirtió la repercusión que esta fuente tenía en la organización retórica de este discurso en relación con el anterior de los uscoques: «ll tono de disputa erudita della fonte si trasmette anche all'orazione, contribuendo a rendere meno percepibile l'antitesi che modella l'impianto retorico, analoga a quella rilevata nel primo discorso».

69. Así lo ha señaló Nider, 2010a, pp. 322-323. 
que empezasteis por la libertad. Pues sola una cosa, y peor que el ser traidor, es no saberlo ser; y el traidor que lo acaba de ser con dicha empieza a ser leal; y el suceso siempre calificó los disinios, y el vencido es el que no tiene razón, ni disculpa, ni consuelo, pues nunca hubo victoria desacreditada. Cuando empezasteis estas defensas convino mirar el fin dellas, mas hoy, empezadas, no se ha de buscar sino el modo de darlas fin. Yo, como vuestro amigo, os busco en la adversidad: padecer quiero vosotros, no mandar. Soldado me ofrezco a vuestras campañas, con tantos reyes por parientes, tantos príncipes por amigos, tantas repúblicas por confederadas. Y en tanto que hago esto, no aventuro mis estados, antes los logro en el mayor peligro de perderlos, por gente que sabe estimar en más la libertad que la vida. Aquí tenéis, no mi consejo, sino mi persona; no mi autoridad, sino mi obediencia (Mundo caduco, p. 160).

Tras las palabras del conde Palatino, Quevedo muestra su efecto en los ánimos de los bohemios. Es un rasgo que también se observará en las orationes del Marco Bruto:

Con tanta maña supo disimular pretensión y mezclar los ruegos y las amenazas que, disfrazando su cudicia, les equivocó la ambición con la humildad; $y$, enternecidos, con agradecimiento orgulloso y aclamación popular, le coronaron por rey de Bohemia (Mundo caduco, p. 160).

El capítulo tercero ( (Don Gonzalo de Córdoba») contiene una vehemente arenga de este a sus tropas, que de nuevo apela a sus afectos mediante la fuerza de la sentenciosidad y la simetría, y donde destaca el uso de la correctio y la metáfora ${ }^{70}$ : la amplificación positiva o negativa de la primera, y la visualización de la segunda, contribuyen sobremanera a la persuasión emocional, finalidad primordial en las arengas. Véase como ejemplo la efectista combinación de metáfora y correctio en el cierre de este discurso:

Despreciada centella somos; confiada vanidad nos busca: acreditemos el proverbio con el suceso; conozcan que la nuestra es confianza y no desesperación, y averigüemos que la suya es osadía y locura delincuente, no valentía ni determinación prudente (Mundo caduco, p. 173).

En conclusión, el entramado narrativo de Mundo caduco deja poco espacio a las clásicas pruebas retóricas, y su argumentación se desarrolla por similares cauces a los vistos en Grandes anales. Los juicios sobre conductas y personajes se integran en la narración mediante la sentenciosidad y la simetría. La amplificación de la correctio tiene un papel fundamental para intensificar la alabanza $y$, sobre todo, el vituperio político, en especial de los venecianos. La metáfora, en fin, continúa aportando la fuerza de la analogía al asunto político. Buena parte de es-

70. Juárez, 2006, pp. 370-371, ha mostrado cómo Quevedo recurre a la eficacia de este tropo en su caracterización positiva de los uscoques y negativa de los venecianos. 
tos recursos se integran en las orationes y arengas que diversos caudillos dirigen a súbditos y tropas, en un nuevo ejercicio donde la evidentia de las palabras contribuye a la persuasión por los afectos. Como sucedía en Grandes anales, donde se presentaba como testigo directo, un Quevedo ahora contemporáneo de los hechos históricos que narra los orienta a su posición política mediante las técnicas que la argumentación retórica ponía al servicio del escritor, sobre todo mediante el manejo del estilo.

\section{Historia, POLÍ́tica, MORAL Y RELIGIÓN}

En el pensamiento de Quevedo, como en el de su época, las reflexiones sobre política y moral se encuentran íntimamente ligadas ${ }^{71}$. La virtud estoica y el pensamiento y la fe católicos sostienen su ideología en materia política. Pero en ese pulso que sostuvieron con la razón de estado, su experiencia vital le llevó a la convivencia con el pragmatismo de estirpe maquiavélica. Es, en suma, una tensión que conoció la reflexión política de su tiempo, apoyada en unos principios morales y religiosos que por fuerza habían de transgredirse en el día a día de la acción de gobierno $^{72}$. Política de Dios y Primera parte de la vida de Marco Bruto son dos obras que se mueven en ese ámbito. A continuación desarrollaré algunas consideraciones generales sobre su argumentación ${ }^{73}$.

\section{Política de Dios}

Escrita en dos partes, la primera fue impresa en 1626; la segunda, en 1655. Por lo que respecta a su redacción, la primera parte pudo haber sido concluida en 1621; la segunda entre 1636 y 1639, y fue quizás ampliada y revisada en la cárcel entre 1639 y $1643^{74}$. La obra se estructura

71. Para la historia de estas conexiones y la evolución del pensamiento político hasta la época de Quevedo, véase el panorama, reflexiones y bibliografía que aporta Rey, 2012, pp. 11-34.

72. El pensamiento y teoría políticos siempre han conocido las contradicciones que plantea su sujeción a una serie de principios morales o religiosos, y la dificultad de aplicarlos o cumplirlos en una práctica de gobierno que a menudo exigía comportamientos contrarios a esos parámetros. Esta diferencia esconde en el fondo una cuestión de índole filosófica que la retórica contemplaba al distinguir entre las quaestiones infinitas o generales y las quaestiones finitas (Lausberg, 1984, §§ 68-78). La sabiduría popular recoge esta distinción en el conocido refrán «Del dicho al hecho hay gran trecho».

73. Otras observaciones sobre la estructura y argumentación de Política de Dios se ofrecen en Azaustre, 2002 y 2004 b.

74. Para estas cuestiones, véanse Crosby, 1959, pp. 72-84; Cacho, 2010 y 2012, pp. 327-330; Díaz Martínez, 2012, pp. 161-166. Jauralde, 1998, pp. 398-399, vinculó las contradicciones en la cronología de las diferentes dedicatorias al proceder argumentativo de Quevedo con este tipo de preliminares, que manejaba en función de sus intereses coyunturales. El análisis de las posibles diferencias que ambas partes presenten en el ámbito de la argumentación es un aspecto que no puede abordarse aquí, pero que debe tenerse en cuenta si se acomete un estudio individual de la argumentación en este tratado. Rey, 2012 , p. 41, nota 86 , ha apuntado para la segunda parte un tono más severo de las advertencias y una mayor desconfianza hacia Felipe IV. Puede señalarse también el aumento 
como un comentario de diversos pasajes de la vida de Cristo que se glosan para extraer de ellos una enseñanza política, especialmente destinada a aconsejar a Felipe IV en lo tocante a las relaciones con sus ministros ${ }^{75}$. En este sentido, se emparenta con el género deliberativo, pues su intención es persuadir al monarca sobre la forma conveniente de gobierno ${ }^{76}$.

La técnica del comentario de un pasaje es fundamental en la organización de bastantes obras de Quevedo. Coinciden en ella diversas tradiciones $^{77}$ : la retórica de la chría y los exempla, que recomendaba dilatar el dicho del personaje o la anécdota del ejemplo con diferentes razonamientos, sentencias y nuevos ejemplos ${ }^{78}$. También la conocida importancia que el comentario de autores tuvo desde la antigüedad hasta el sistema de enseñanza humanista, y en el de los jesuitas en el que se formó Quevedo ${ }^{79}$. Dentro de la esfera religiosa, el comentario se desarrolló en los ejercicios de exégesis bíblica ${ }^{80}$ y en determinadas modalidades de sermón ${ }^{81}$, particularmente en la homilía, que se basaba en recorrer

de citas patrísticas en la segunda parte (49) frente a la primera (13), que en su día señaló López Poza, 1992, pp. 66-83, 231, 264-268.

75. La bibliografía que estudia la obra en relación con el pensamiento de Quevedo es muy abundante; véanse, entre otros, Martínez Burgos, 1945; Bleznick, 1955; Pérez Carnero, 1970 y 2007; Roncero, 1991; Rey, 2012, pp. 39-50, con abundantes documentación y bibliografía.

76. Peraita, 1997, pp. 82-90 y 98-99. Para el uso de las Escrituras con fines políticos en los memoriales de Quevedo, véase Rey, 1993, pp. 261 y 265. Fernández Mosquera, 1998, señala cómo esa mixtura de lo religioso y lo político fue la base de muchas censuras a esta obra de Quevedo.

77. Expongo estas consideraciones con más detalle en Azaustre, 2004b, pp. 23-32.

78. Para el desarrollo de la chría, véase lo afirmado por Hermógenes y Aftonio (Ejercicios de retórica, pp. 180-181 y 220). La amplificación del exemplum con comentarios se desarrolló en los modi locupletandi exempla incluidos en la Copia de Erasmo, obra muy influyente en diversas retóricas áureas. Véase un estudio de la retórica del exemplum en Aragües Aldaz, 1999; de los modi locupletandi exempla de Erasmo se ocupa en las pp. 256263. Peraita, 1999, analizó la influencia de esta obra en la construcción de Política de Dios.

79. Véase como botón de muestra, Mathieu-Castellani, 1990. López Poza, 1997, p. 63, subraya la importancia que en la formación de Quevedo tuvieron los libros o repertorios organizados como la declaración a uno o varios lugares de autores antiguos.

80. Véase, por ejemplo, San José Lera, en fray Luis, Exposición, pp. 17-42, 28 y 62. Compagnon, 1979, pp. 162-163, repasa los principales métodos para el comentario de la letra sagrada: escolio (breve nota marginal que aclara un pasaje difícil), homilía (sermón que reúne una serie de escolios sobre diferentes lugares bíblicos para edificar a los fieles) y comentario (obra más amplia y ambiciosa, que explica un libro bíblico de forma exhaustiva y rigurosa). Blanco, 1992, pp. 520-522, vincula la estructura de obras como el Rómulo, Vida de Marco Bruto, La caída para levantarse, Job y Política de Dios a la exégesis tropológica, que asocia a los motivos del texto bíblico una sentencia o mensaje morales. Desde este punto se explica la aguda estructura de esas obras que parten del texto de una fuente sagrada o profana- para extraer analogías de índole moral o política en consonancia con la ideología del autor: «On voit à quel point ce traitement conceptiste d'un texte source le rend infiniment malléable et voile à peine son exploitation unilatérale au service des idées préconçues de l'écrivain» (Blanco, 1992, p. 422).

81. La crítica ha señalado este vínculo de Política de Dios con la literatura y estilo del sermón y la oratoria sacra; véanse Hafter, 1959, p. 104; Martín Pérez, 1980, pp. 170 y 175; Lida, 1981, pp. 172-178; Clamurro, 1991, pp. 123-126 y 130-132; Ghia, 1994, pp. 
y comentar distintos lugares del Evangelio («exposición de la letra del Evangelio», en palabras de fray Luis de Granada). Géneros literarios como las Vidas o las Hagiografías jalonaban la narración biográfica con sustanciosos juicios morales, políticos o religiosos, según el caso ${ }^{82}$.

Sobre esa estructura de comentario, la base de la argumentación quevediana en Política de Dios se halla, en primer lugar, en el manejo de la cita bíblica, que actúa como exemplum ${ }^{83}$. Se trata, en este caso, de los pasajes de la vida de Cristo seleccionados como ejemplo bíblico del que extraer por analogía una enseñanza política. La selección de esos pasajes nos muestra al Quevedo maestro de la agudeza a la hora de encontrar semejanzas entre dichos episodios y la realidad de la corte de Felipe $\mathrm{IV}^{84}$. Se conforma así una suerte de alegoría marco, en la que Cristo actúa como monarca y sus apóstoles como ministros, y que se refuerza mediante la aplicación del léxico político a los episodios bíblicos (Peraita, 1997, pp 95-96). Como sucede habitualmente cuando se aduce una autoridad o un exemplum, Quevedo se esfuerza en acercarlo al sentido político que pretende otorgarle: «Letra por letra, parece que el texto del evangelista está ocasionando a los reyes) (Política de Dios, p. 305). Quevedo manifiesta explícitamente en varias ocasiones las posibilidades que en este sentido ofrecen las Escrituras ${ }^{85}$ :

Es tan fecunda la Sagrada Escritura que sin demasía ni prolijidad sobre una cláusula se puede hacer un libro, no dos capítulos [...]

Nada olvidan los santos: debajo de sus puntos se disimulan aquellas sutilezas políticas de que hacen tanto caudal los autores profanos ${ }^{86}$ (Política de Dios, p. 284).

59-69; Fernández Mosquera, 1998; Peraita, 1997, pp. 69-73, 99; 2001; Azaustre, 2004b; Rey, 2012, p. 47.

82. Lo señaló Nider, en Quevedo, La caída, pp. 60-78, al estudiar las fuentes e influencias en la estructura de esta obra de Quevedo y algunos procedimientos retóricos del Job (Nider, 1995, p. 215). Lo indica también Vaíllo, 2000, p. 404, en su análisis de la Vida de Marco Bruto.

83. Véase al respecto Peraita, 2000.

84. Clamurro, 1991, pp 126 y 133, ha señalado cómo la fuerza y validez de la lección política extraída del pasaje bíblico se encuentra en la agudeza de la analogía. La importancia del exemplum como base de la inventio en Política de Dios ha sido destacada por Peraita, 2000, quien también ha subrayado la libertad con la que Quevedo interpreta los textos bíblicos para adecuarlos a su intención política (Peraita, 1998, pp. 1208-1210). Esta agudeza en la conexión analógica del exemplum o en el manejo de los tropos es el correlato retórico de lo que, desde una perspectiva exegética, se analiza en los distintos niveles de interpretación alegórica y tropológica del texto bíblico; véanse Peraita, 2001, p. 202; Fernández Rivera, 2010; Rey, 2012, pp. 43-44.

85. Pérez Carnero, 2007, pp. 192-214, señala cómo Quevedo se esfuerza en adscribir al sentido literal de las Escrituras la enseñanza política que extrae de su texto, pues, según santo Tomás, solo ese sentido literal tenía fuerza probatoria. Se apoyaba para ello en la general opinión que en su tiempo reconocía la multiplicidad de sentidos literales del texto bíblico. Sobre esta premisa, Quevedo ejercita su dominio de la agudeza para acomodar la letra bíblica a la intención política.

86. Como indica Cacho, 2012, es una idea que Quevedo reiterará en las obras de sus últimas décadas. Véase lo dicho en la nota 104 sobre la creciente orientación religiosa de 
Ese ingenio en acercar el episodio bíblico al asunto político llevó a Quevedo a extremos de novedad de cuyos peligros era consciente. Un caso muy claro se produce en el capítulo diecisiete de la segunda parte, cuando Quevedo interpreta que no fue ausencia el que Cristo permaneciese en Jerusalén cuando sus padres, sin advertirlo, habían emprendido ya el camino de vuelta, pues cumplía con su oficio ${ }^{87}$. Extraigo de la extensa consideración -que ocupa todo el capítulo- el pasaje donde Quevedo subraya la novedad de su lectura ${ }^{88}$ :

Este pedazo de historia de Jesucristo tengo por el que está retirado en más dificultosos misterios [...] Yo, como el camino que sigo es nuevo, no puedo valerme de otro intérprete que de la consideración de la vida de Cristo. Y si no me declarare al juicio de todos, séame disculpa que, en lugar y de palabras que el evangelista afirma que la madre de Dios y Josef no entendieron lo que les dijo («Et ipsi non intellexerunt verbum») ${ }^{89}$, forzosa me parece a mí la ignorancia, y en ella estaré sin otra culpa que la de haber osado acometer lugar tan escondido (Política de Dios, pp. 486-487).

Destaca también el uso del ejemplo como parte de un argumento comparativo, característica que se observa en otras obras de Quevedo, como los memoriales en favor del apóstol Santiago. Partiendo de la conducta que ejemplifican Cristo, sus apóstoles u otros personajes bíblicos, se extrae por inducción (locus a minore ad maius) o deducción (locus a maiore ad minus) la lección que deben tomar reyes y ministros. Señalo dos de los muchos casos que se encuentran en Política de Dios:

Vio Caín que iba a Dios más derecho el humo de la ofrenda de Abel que el de la suya, pareciole hacía Dios mejor acogida a su sacrificio, sacó su hermano al campo y quitole la vida. Pues si la ambición de los que quieren privar es tan facinorosa y desenfrenada que, aun advertida por Dios, hizo tal insulto, ¿qué deben temer los príncipes de la tierra? Apuro más este punto y alzo la voz con más fuerza: señor, si es tan delincuente el deseo en el ambicioso por que dél reciba el señor primero y de mejor gana, ¿dónde llegará la iniquidad y disolución de los que compitieren entre sí sobre quién recibirá más del rey? (Política de Dios, pp. 213-214)

El rey es menester que asista a todo y que abra los ojos por que los suyos no pierdan la fe. Mire vuestra majestad cuán descaecidos estaban los apóstoles porque durmió un poco Cristo, sabiendo que él dice de sí: «Yo duermo, etc.». La vista de los príncipes influye coraje; y el miedo -que sólo precia la salud y pone la honra en la seguridad- suele reprehenderse con el respeto. No le queda qué hacer al rey que asiste y mira, ni qué esperar al que hace lo contrario. Si en la república de Cristo, Dios y hombre, en cerrando

las citas de autoridades usadas por Quevedo.

87. Lucas, $2,42-44$.

88. Según Pérez Carnero, 2007, p. 194, este pasaje muestra que Quevedo no suele recurrir en Política de Dios al apoyo de exégetas consagrados, pues no encuentra en ellos las aplicaciones políticas que busca otorgar al texto bíblico.

89. Lucas, $2,50$. 
los ojos, estuvieron para dar al través sus allegados, ¿qué se ha de temer en los reyes que se duermen con los ojos abiertos? (Política de Dios, p. 244).

Sin salir del argumento por comparación, el de tipo antitético tiene también una destacada presencia para contraponer buenas y malas conductas en la esfera política. Señalo un par de casos: el primero es de índole más general; el segundo opone la conducta de Cristo y su gobierno a la de los reyes del mundo:

Los maliciosos otro camino siguen que los beneméritos: en aquéllos es la humildad cautelosa, y esfuérzase a disimular ambición y atrevimiento; y en éstos es santa y encogida (Política de Dios, p. 278).

¿Qué república tan diferente de la que mantiene los reyes del mundo! Aquí los ricos no pueden entrar, y entre nosotros no saben salir. Llama a los pequeños y despide a los poderosos, no porque no admite el reino a todos, sino porque ellos se son estorbo a sí; y en este mundo embarazan y ocupan la entrada a los pobres, y en el otro (como la puerta es estrecha y el camino angosto) ni por el uno ni por la otra caben (Política de Dios, p. 294).

Junto a los lugares bíblicos y la agudeza en su aplicación como exempla, debe señalarse la importancia que adquieren los recursos oratorios del sermón, orientados sobre todo a la persuasión afectiva ${ }^{90}$. La frecuencia del apóstrofe que interpela al monarca y de los verbos en imperativo y subjuntivo son claras muestras de ese tono de vehemencia. Esta persuasión afectiva es muy frecuente en los finales de los distintos capítulos, concebidos como breves y vehementes perorationes que apelan al monarca; las figuras patéticas y de repetición, junto con la simetría sintáctica, cobran especial relieve en estos pasajes:

Señor, nazca de su virtud el ministro; conozca que le engendró el mérito, no el padre; tenga por hermanos los que más merecieren, por hijos los pobres, que, entonces por los padres que deja viene a merecer que le tengan por tal todos los que son cuidado de Dios nuestro señor, que se lo encarga. Seranle alabanza los súbditos y premio sus desvelos, y podrá ir a vuestra majestad, que en tan nueva vida y en tan florecientes años trabaja como padre y no como dueño, y atiende a que los que le asisten se desembaracen de lo que el Evangelio prohíbe con distinción tan infalible y tan grande (Política de Dios, pp. 272-273).

Sacra, católica, real majestad, dé Dios a vuestra majestad ministros imitadores del Bautista, que sean medios iluminados y voz del que clama en el desierto, que vistan pieles de camellos y no de leones y lobos, que coman langostas y no sean langostas que coman los pueblos, que contradigan las grandes mercedes antes que solicitarlas, que digan lo que no han de callar y no callen lo que deben decir (Política de Dios, p. 442).

90. Véanse las referencias de la nota 81. 
Esa persuasión afectiva se concreta a menudo en frecuentes enumeraciones donde las figuras de entonación y repetición conviven con el paralelismo para alabar o censurar a monarcas y ministros, advertirles de los peligros que los acechan o exhortarles al recto cumplimiento de su tarea de gobierno. El primer pasaje advierte al rey de los peligros de los malos ministros; el segundo combina los citados recursos con la antítesis que opone a Cristo y los malos monarcas; el tercero y el cuarto vituperan con vehemencia a los malos reyes ${ }^{91}$ :

¡Cuántas veces entenderá vuestra majestad que uno es ministro y que negocia, y a pocos lances conoce que es Satanás y que le tienta! Si quisiere que vuestra majestad haga de las piedras pan, no hacerlo y convencerle, que así se castiga su cudicia. Si pidiere que se despeñe vuestra majestad con pretexto de santidad y buen celo, castigarle con reprehensión la insolencia. Si propusiere que le adoren y tocaren en la reverencia y dignidad real, llamarle Satanás - que es su nombre-, despedirle como a Satanás, y castigarle como a sacrílego y traidor (Política de Dios, p. 319).

El raposo rey, a quien aconseja la maña, la ambición y la tiranía, ése tiene cuevas donde reclinar la cabeza, donde esconderse, donde no parezca rey; mas el hijo del hombre, el rey que conoce que es hombre y que lo son los que gobierna, y que es rey para ellos por voluntad de Dios, ése no tiene cuevas donde esconderse ni donde inclinar la cabeza (Política de Dios, pp. 266-267).

¿Quién contará los príncipes a quien ha depuesto su impaciencia, los que por ella han sido cuchillo de sus reinos, veneno de sus buenos vasallos, fin de sus grandezas, vituperio de sus ascendientes, infamia de los siglos, escándalo a los por venir y abominación a la memoria de las gentes? ¿Quién, sin perder la paciencia, pudo ser cruel? ¿Quién avaro? ¿Quién soberbio? ¿Quién adúltero? ¿Quién tirano? (Política de Dios, pp. 517-518).

¿Quién entre los innumerables hombres que lo han sido, o por elección o por las armas o adoptados o por el derecho de la sucesión legítima, ha dejado de ser juntamente rey y reino de sus criados, de sus hijos, de su mujer u de los padres u de sus amigos? ¿Quién no ha sido vasallo de alguna pasión, esclavo de algún vicio? Si los cuenta la verdad, pocos. Y éstos serán los santos que ha habido reyes (Política de Dios, p. 221).

Alabanza y, sobre todo, advertencia y vituperio son las intenciones que explican que la vehemencia haya sido el cauce argumentativo preferido por Quevedo en muchos pasajes de Política de Dios ${ }^{92}$. A esas intenciones sirve también la correctio, recurso ya comentado en los anteriores escritos histórico-políticos, y que tiene una gran importancia en las dos partes de este tratado. Mediante su particular disposición antitética $(x$, no y o no $y$, sino $x$ ) se emplea en Política de Dios en tres grandes direcciones: 1) aconsejar la conducta correcta oponiéndole la negación de la perniciosa, 2) subrayar la censura de malos reyes y ministros o la ala-

91. Su análisis estilístico se aborda en Azaustre, 1996, pp. 98-111 y 136-142.

92. Más detalles en Azaustre, 1996, pp. 104-105 y 137-138. 
banza de Cristo y quienes siguieron su ejemplo, 3) desvelar peligrosas intenciones ocultas bajo falsas apariencias:

A vuestro cuidado, no a vuestro albedrío, encomendó las gentes Dios nuestro Señor; $\mathrm{y}$ en los estados, reinos y monarquías os dio trabajo y afán honroso, no vanidad ni descanso (Política de Dios, p. 206).

La voz de la adulación, que con tiranía reina en los oídos de los príncipes, esforzada en su inadvertencia, suele halagarlos con decir que bien pueden echarse a dormir (quiere decir descuidarse con los ministros). Éste es engaño, no consejo (Política de Dios, p. 262).

Junto a los anteriores recursos, y a menudo en combinación con ellos, debe señalarse la importancia de la sintaxis sentenciosa y simétrica, que transmite con solemnidad y fuerza la advertencia moral y políti$\mathrm{ca}^{93}$; en los siguientes ejemplos aparece junto a la antítesis:

Muchos son buenos si se da crédito a los testigos; pocos, si se toma declaración a sus conciencias. En los malos, en los impíos se ha de mostrar la misericordia; por los delincuentes se han de hacer finezas (Política de Dios, p. 232).

Rey que pelea y trabaja delante de los suyos, oblígalos a ser valientes; el que los ve pelear, los multiplica y de uno hace dos. Quien los manda pelear y no los ve, ése los disculpa de lo que dejaren de hacer, fía toda su honra a la fortuna; no se puede quejar sino de sí sólo. Diferentes ejércitos son los que pagan los príncipes que los que acompañan: los unos traen grandes gastos, los otros grandes vitorias; los unos sustenta el enemigo, los otros el rey perezoso y entretenido en el ocio de la vanidad acomodada. Una cosa es en los soldados obedecer órdenes; otra, seguir el ejemplo: los unos tienen por paga el sueldo; los otros, la gloria (Política de Dios, p. 242).

Finalmente, las posibilidades argumentativas de la metáfora a través de su capacidad visual, ya testimoniada en las obras anteriores, adquieren una importancia muy destacada en Política de Dios para recordar de manera gráfica a Felipe IV los peligros y obligaciones inherentes a su cargo, o para retratar conductas de quienes lo rodean. El valor metafórico estaba ya muy presente en el texto bíblico, y su exégesis propiciaba esta interpretación alegórica, no siempre bien admitida por sus posibles excesos ${ }^{94}$. Quevedo parte de esa base metafórica para ampliarla o matizarla en relación con la intención política que le otorga. Ya uno de los pasajes arriba citados se hacía eco de ello en su referencia a las langostas. Señalo algunos otros de los muchos ejemplos del tratado:

93. Azaustre, 1996, pp. 232-233.

94. Véanse Peraita, 1997, p. 79, y Azaustre, 2004b. Cerdan, 2000, pp. 94-95, ha analizado en varias homilías la importancia de distintos tropos y figuras retóricas (símil, sermocinatio, apóstrofe...). Pérez Carnero, 2007, pp. 196-213, ha advertido la importancia de varias de estas metáforas en su análisis de diversos ejemplos de exégesis en Política de Dios. Para la caracterización de la metáfora en la sátira quevediana, véase Schwartz, 1984; en la poesía de Quevedo, Arellano, 2003; González Quintas, 2006. 
Han de ser voz en el desierto ${ }^{95}$. Yo entiendo aquí eco, porque el eco por sí no dice nada: repite lo que dice otro, y no todo, sino los últimos acentos. Así ha de ser el criado, que ha de decir lo que el rey dice, y no tanto como él, unos finales; no al revés, que el rey diga lo que dijere el eco. Y cuando lo quieran entender de otra suerte, ha de ser voz, no lengua, que es señal que ha de ser formado y no ha de formar. Y no basta que sea voz, sino que lo sea en desierto, sin pompa afectada, sin acompañamientos ambiciosos, compitiendo el cortejo al rey (Política de Dios, p. 298).

Dice: «a dar testimonio de la luz» ${ }^{96}$. Esto le excluye de ciego, tenebroso y anochecido, y enemigo del día y de la luz. Añade que ha de ser "para que crean todos por él», mas no en él, sino en el Señor por él. Dice que cél no era luz», cláusula muy importante. Es muy necesario, señor, escribiendo de tales ministros, referir lo que no son junto a lo que deben ser. Si el criado es luz, será tinieblas el príncipe; no ha de ser tampoco tinieblas, que no podría dar testimonio de la luz [...] Ha de ser el buen ministro luz encendida, mas no se ha de poner ni sepultar debajo del celemín para alumbrar sus tablas solas y sus tinieblas, sino sobre el candelero: disposición es evangélica ${ }^{97}$. Ha de ser vela encendida, que a todos resplandece y sólo para sí arde, a sí se gasta y a los demás alumbra; mas el ministro que para todos fuese fuego y para sí solo luz, que alumbrándose a sí consumiese a los otros sería incendio, no ministro (Política de Dios, pp. 437-438).

Era pozo, y le llama fuente el evangelista ${ }^{98}[\ldots]$ como el Espíritu Santo por san Juan hablaba al suceso para el misterio, y sabía que la mujer buscaba pozo y agua muerta, y que en el pozo había de hallar al que es fuente de agua viva, llamola a sí, previniendo la maravilla, y llamó fuente al pozo, porque la historia se cumplió en la fuente [...] Señor, los pretendientes, los sedientos, los allegados, os quieren pozo hondo y obscuro y retirado a la vista, por que solos ellos puedan sacar lo que quisieren. Éstos, señor, que alcanzan con soga y no con méritos, paguen con su cuello al esparto lo que le trabajan con el caldero. Pozo os quieren, señor, fuente sois, y tal os eligió Jesucristo. Ellos os quieren detenido y encharcado para sí, y Dios, difuso y descubierto para todos. Corred como fuente, pues lo sois; y para quien os quiere pozo, sed sepultura (Política de Dios, p. 450).

En bastantes ocasiones, esa explicación alegórica que parte de la metáfora bíblica se remata con un locus a comparatione, recurso que, como hemos visto, es muy usado por Quevedo para amplificar la advertencia política $^{99}$ :

95. Juan, 1, 23.

96. Juan, $1,6-8$.

97. Cacho, en Quevedo, Política de Dios, p. 438, nota 366, indica que «Quevedo parafrasea la parábola de la lámpara, recogida en Marcos, 4, 21-22; y Lucas, 8, 16-17, que representa la imposibilidad de mantener algo oculto sin que se descubra tarde o temprano: "Non est enim aliquid absconditum, quod non manifestum"»".

98. Juan, 4, 4-14.

99. Véase también el que se construye sobre el episodio de la conversión de las piedras en panes (Mateo, 4, 3) en Política de Dios, pp. 315-317, o el que parte del episodio de los mercaderes del templo (Juan, 2; Marcos, 11) en Política de Dios, pp. 307-308. 
¿Qué cosa es una república sino una piscina ${ }^{100}$ ? ¿Qué ha de ser un rey sino un ángel que la mueva y la dé virtud? ¿Qué cosa son los pretendientes y los beneméritos y los agraviados y los oprimidos y los pobres y las viudas, sino enfermos que aguardan salud de las aguas de la justicia, y de la misericordia y grandeza del rey? Pero si los ministros son tales que prefieren unos a otros por su voluntad y olvidan al que más necesidad tiene, obligarán a que venga Dios a desagraviar los desvalidos.

Pues si en la piscina que revolvía un ángel que bajaba del cielo había esta desorden, ¿qué habrá en la del gobierno y los cargos y mercedes, que las más veces las revuelve Satanás, y las más veces las revuelven los hombres? (Política de Dios, p. 303).

En la misma línea, la metonimia que manifiesta intenciones y conductas mediante partes del cuerpo resulta muy frecuente para expresar de modo gráfico la advertencia y censura políticas ${ }^{101}$. La presencia del rey en los asuntos de gobierno, sin delegar en ministros o allegados, se expresa así vivamente mediante las metonimias de los ojos, las orejas y los oídos:

En los peligros, el rey que mira manda con los ojos. Los ojos del príncipe es la más poderosa arma, y en los vasallos asistidos de su señor es diferente el ardimiento: descuídase el valor con las órdenes y discúlpase el descuido (Política de Dios, p. 241).

Los reyes nacieron para los solos y desamparados, y los entremetidos para peligro y persecución y carga de los reyes: déstos han de huir hacia aquéllos. Quien solicita y pretende el cargo le engaita o le compra o le arrebata; quien se contenta con hacerse por la virtud digno dél, le merece. A estas cosas no se ha de acudir por relaciones y por terceros: los ojos y los oídos del rey han de ser los más frecuentes ministros (Política de Dios, p. 304).

El siguiente pasaje, que cierra el capítulo 2 de la segunda parte, constituye una hábil combinación de metáfora (guante) ${ }^{102}$ y metonimias (cara, manos, dedos, ojos) apoyada en el pasaje bíblico, con la misma intención de señalar al monarca la conveniencia de que desempeñe en persona sus obligaciones:

Empero, el verdadero rey Cristo Jesús ni se divierte de su oficio ni consiente que el amor tierno y santo de los suyos le divierta, y por eso dice:

100. Juan, 5, 5-8.

101. Privilegio esa relación semántica (concreto-abstracto) y no la de parte del cuerpo en relación con la totalidad de este; en virtud de esa jerarquía, califico los ejemplos como metonimias y no como sinécdoques; véase Lausberg, 1984, § 568, 2. Fernández Rivera, 2010, ha estudiado este método de (fragmentación corporal» en relación con la interpretación alegórica de la exégesis bíblica, así como con géneros literarios y prácticas médicas de la época.

102. Cacho, en Quevedo, Política de Dios, p. 364, nota 112, indica que Quevedo usó esta misma metáfora para referirse a Tomás de Saboya en una carta de 1642, y en otra de 1643 llamó «rey guante» a Luis XIII por su dependencia de Richelieu. 
“Firmavit faciem suam in Hierusalem. Afirmó su cara hacia Jerusalén» ${ }^{103}$, donde había de padecer. Toda la salud del gobierno humano está en que los príncipes y monarcas afirmen su cara al lugar de su obligación, porque, si dejan que las manos de los que se la tuercen la descaminen, mirarán con la codicia de sus dedos y no con sus ojos. Aquel señor que, no queriendo imitar a Cristo, se deja gobernar totalmente por otro no es señor sino guante, pues sólo se mueve cuando y donde quiere la mano que se lo calza (Política de Dios, pp. 363-364).

Ejemplo bíblico y moción de afectos son, junto al eficaz acompañamiento de la metáfora y la metonimia en la alegoría bíblica, los principales recursos de argumentación de Política de Dios. Al margen de las citas tomadas de las Escrituras y los autores cristianos, las autoridades no adquieren la importancia que cobran en otros tratados ${ }^{104}-$ tal vez porque las analogías que plantea Quevedo no se encontraban en ellasy la argumentación basada en raciocinios no resulta especialmente destacada. Quevedo ha preferido trasladar el ejemplo de Cristo al terreno de la política y del gobierno; instalado en ese marco, la agudeza en la analogía y la persuasión afectiva -base de la predicación y el sermónofrecen un cauce más adecuado para transmitir al monarca recomendaciones y advertencias sobre los peligros que le acechan en la difícil acción del gobierno.

\section{Primera parte de la vida de Marco Bruto ${ }^{105}$}

El afán de Quevedo por volver sobre sus textos se muestra de manera palmaria en esta obra. No fue publicada hasta 1644, y el epistolario de Quevedo nos deja el rastro de su preocupación por un proyecto de gran envergadura, para el que concibió una segunda parte que la muerte le impidió terminar ${ }^{106}$. Volvemos a encontrarnos, pues, con un rasgo destacado en la prosa doctrinal de Quevedo: los proyectos no conclui-

103. Cacho, en Quevedo, Política de Dios, p. 364, nota 111, señala que «Parece una cita de memoria de Lucas, 9, 51: "et ipse faciem firmavit ut ire in Ierusalem" ".

104. Tras las citas bíblicas, base en la configuración de la obra, destacan las patrísticas y teológicas y, con mucha menor frecuencia, las de autoridades no religiosas. Para las citas patrísticas en Política de Dios, véase López Poza, 1992, pp. 66-83, 264-268, 231. Lopéz Poza, 1992, pp. 215-218, constató el creciente interés por la patrística por parte de Quevedo, en consonancia con la creciente orientación de su prosa hacia las materias morales y religiosas. Pérez Cuenca, 2003, pp. 299-303 y 2004, pp. 450-451, dio noticia del ejemplar de la Cathecheses de san Cirilo de Jerusalén encontrado en la BNE; Nider, 2013b, estudió y editó dichas anotaciones, que Quevedo empleó en La cuna y la sepultura, Política de Dios, Providencia de Dios, La constancia y paciencia del santo Job y Sueño del infierno.

105. Vaíllo, 2000, p. 393, y Alonso Veloso, 2012, han mostrado que en rigor este debiera ser el título de la obra. Utilizaré la fórmula abreviada Marco Bruto para referirme a ella en el texto de manera más fluida.

106. Véanse en el Epistolario (pp. 468-492) las cartas CCL, CCLIV, CCLIX, CCLXIII a CCLXVI, CCLXXII, CCLXXIII, CCLXXVIII, donde se recoge su labor corrigiendo la primera edición, sus quejas por las erratas en ella contenidas y sus esfuerzos por terminar la segunda parte. 
dos. La magnitud del Marco Bruto y su compleja problemática obliga a señalar de forma somera las cuestiones que deberá abordar en detalle un estudio de su argumentación ${ }^{107}$.

El Marco Bruto se organiza en tres secciones formadas por la «Vida de Marco Bruto», la "Cuestión política» y las «Suasorias sexta y séptima de Séneca el retórico» ${ }^{108}$. A ellas les preceden los obligados preliminares legales y unos preliminares literarios de gran riqueza ${ }^{109}$. Es este un rasgo que se observa en otras obras prosísticas de Quevedo. En Marco Bruto encontramos una de sus mejores muestras por la variedad de esos textos ${ }^{110}$. Así, la dedicatoria a don Rodrigo Díaz de Vivar, duque del Infantado, constituye un clásico ejercicio de captatio benevolentiae al que Quevedo añade la elevada opinión que le merece el Marco Bruto, lo que redunda en la ya mencionada atención que le dedicó hasta sus últimos días. A ello debe unirse un rasgo apuntado por Josette Riandière (1994, p. 981): Quevedo ofrece el ejemplo del duque del Infantado, vencedor de los rebeldes catalanes en Fraga, al Marco Bruto derrotado en Farsalia; esa transgresión histórica enriquece la perspectiva del exemplum y se observará en varias ocasiones más a lo largo de la obra. Otro preliminar es la descripción de la medalla de Bruto. Junto a la captatio benevolentiae de don Martín de la Farina de Madrigal, capellán de honor del rey, se desarrolla un ejercicio descriptivo de la moneda que conecta la severidad del rostro de Bruto con su carácter ${ }^{111}$. Para probar su semejanza con Marco Bruto, Quevedo traduce una cita de Cicerón ( $A d$ Atticum, XIv); a ella añade un comentario de gran interés por mostrar una referencia a las controversias de Séneca el retórico, autor presente en las dos últimas secciones de la obra, y por justificar explícitamente las opciones que Quevedo ha preferido en su traducción, rasgo que avanza una característica fundamental en todo el texto: las modificaciones interesadas en la traducción y la cita de fuentes con la finalidad de transmitir mejor su punto de vista.

El siguiente prólogo -«A quien leyere»- cumple la clásica función de mostrar el objetivo de la obra. Quevedo avanza ya un rasgo destacado en toda ella: la paradoja que muestra la complejidad de los comportamien-

107. Rey, 2012 , pp. 53-75, ofrece un completo panorama de los asuntos que la obra aborda en las esferas política y moral, con abundante bibliografía. En las notas señalaré también algunos de los estudios que se han ocupado de diversos aspectos de esta obra.

108. Para los avatares del texto, véanse Duque de Maura, 1945; Jauralde, 1982; Martinengo, 1998a, pp. 91-96; Fernández Mosquera, 2000, pp. 78-79; Vaíllo, 2000, pp. 393-394; Rey, 2012, pp. 51-52; Alonso Veloso, en Quevedo, Primera parte, pp. 643-648.

109. Riandière, 1994, pp. 980-983, ha analizado estos textos preliminares mostrando la coherencia con la primera sección de la obra. Cappelli, 2001, pp. 72-74, los ha estudiado en relación con el «Juicio que de Marco Bruto hicieron los autores en sus obras».

110. Véanse al respecto Riandière, 1976, pp. 57-59, y Cappelli, 2001, pp. 73-75.

111. Véanse más detalles en Roig Miranda, 1980, p. 144; Riandière, 1994, pp. 982 983, y Krabbenhoft, 1994, pp. 97-99. 
tos humanos ${ }^{112}$. A través de ella y de las vidas de Bruto y César intentará mostrar los peligros de esas dobleces y pliegues del hombre en las esferas política y moral. A esta finalidad se une la declaración de que tenía la obra finalizada en 1631 y una lista de las que en ese tiempo le faltaron ${ }^{113}$.

El preliminar más destacado es, sin duda, el titulado «Juicio que de Marco Bruto hicieron los autores en sus obras». Traduce allí Quevedo las opiniones que el personaje mereció a diversos autores que ordena cronológicamente, desde Cicerón a Michel de Montaigne ${ }^{114}$. Su interés argumentativo radica en dos aspectos: por un lado, el recurso a las auctoritates en la presentación del personaje. Quevedo incluye tras los oradores antiguos a Dante y Montaigne, lo que avanza una estrategia similar que posteriormente llevará a cabo con el exemplum; además, el juicio de estos autores alterna rasgos positivos y negativos de Bruto, lo que permite observar en este preliminar esa compleja perspectiva dual que presidirá la obra. Por otra parte, destaca la traducción quevediana de esas citas de autoridades. Alessandro Martinengo (1998c, p. 110) señaló la alteración que Quevedo llevó a cabo en la traducción de los pasajes de Séneca, con el fin de que ofreciesen una "posición especular y contrapuesta» en la presentación de Bruto, la cual prefigura la dualidad que se desarrollará en la posterior sección «Vida de Marco Bruto». Federica Cappelli (2001) estudió las leves licencias que Quevedo adopta en la traducción de estas citas de autoridades, que se orientan de manera consciente a subrayar o atenuar ciertas ideas de acuerdo con su planteamiento del asunto. Será un rasgo de gran importancia también en la parte central de la obra, cuando Quevedo retoque la traducción del texto de Plutarco para anticipar las ideas que desarrollará en su posterior comentario.

Como se ha indicado, el texto del Marco Bruto propiamente dicho consta de tres secciones: “Vida de Marco Bruto», "Cuestión política» y «Suasorias sexta y séptima de Séneca el retórico». Esta marcada división plantea el problema de la unidad del conjunto, que la crítica ha estudiado en profundidad con opiniones no siempre coincidentes que a continuación resumo: René Bouvier (1929, p. 160) afirmó que carecía de plan; González de la Calle (1965) no consideró las «Suasorias» como parte de la obra, y esa difícil integración de las «Suasorias» se observa en otros trabajos ${ }^{115}$. Josette Riandière (1976 y 1994) analizó en detalle la estructura de varias de sus secciones; demostró la cohe-

112. El importante papel de la paradoja en el Marco Bruto fue estudiado por Roig Miranda, 1980.

113. Algunas, como la traducción de varias controversias de Séneca el retórico, han sido rescatadas y estudiadas por Fernando Plata, 2001.

114. Sobre esta sección, véanse Riandière, 1994, pp. 981-982; Cappelli, 2001.

115. Así por ejemplo, Gendreau, 1977, que las estudia en lugares distintos de su trabajo: la «Vida de Marco Bruto» en el capítulo 2 de la segunda parte (pp. 233-249); las «Suasorias» en el capítulo 1 de la tercera parte (pp. 361-372). Para Gendreau, 1977, pp. 231-232, la primera sección habría sido redactada en 1631, y las dos siguientes en torno a 1644. Con todo, esa ubicación no implica necesariamente una postura sobre la unidad de la obra, pues no es este el asunto que ocupa dicho estudio. 
rente integración de los preliminares, la «Vida» y la «Cuestión política», y subrayó la necesidad de juzgar la organización de la obra sobre presupuestos retóricos y estructurales de su tiempo (Riandière, 2000, p $360)^{116}$. Kenneth Krabbenhoft (1994, pp. 21-36) defendió la unidad del conjunto de las tres partes, fundamentada en la reiteración de tópicos ${ }^{117}$. Alessandro Martinengo (1998a) llevó a cabo un minucioso estudio de las tres secciones en donde defiende la unidad del conjunto incluyendo las «Suasorias»"118. En su opinión, Quevedo concibió estas suasorias como parte del libro, pues entroncan con la «Cuestión política» por el esquema retórico cercano a la controversia, y con la «Vida de Marco Bruto» por el modelo de la traducción interpretativa, la selección de textos seguidos de comentarios personales y los personajes que las protagonizaban $^{119}$. Concuerda con Martinengo la opinión de Carlos Vá́llo (2000, p 394), quien considera que las «Suasorias» presentan «sus particularidades propias» y que «agregadas a última hora y quizás por imposiciones editoriales, las dos Suasorias se integran plenamente por los personajes y la continuidad histórica en el cañamazo histórico del resto de la obra». Finalmente, Alfonso Rey (2012, pp. 52-53) afirmó que

Marco Bruto posee una unidad laxa, similar a la de otras obras quevedianas que avanzan por agregación de nuevos motivos, en las cuales la diversidad estructural es compatible con la conexión entre las ideas y temas desarrollados en cada una de las partes en que se divide el todo.

Esa tripartición de secciones donde conviven diferencias y elementos unificadores se relaciona también con la posibilidad de distintas fechas de redacción para ellas. Una posibilidad sería que la «Vida de Marco Bruto» y la “Cuestión política» hubieran configurado lo que podríamos llamar primera versión de la obra. La “Cuestión política» constituiría así una reflexión sobre el comentario a la vida de Marco Bruto

116. Véase un esquema de su organización estructural en Riandière, 1994, pp. 986991, donde la «Cuestión política» se integra como un coherente epílogo a la «Vida de Marco Bruto».

117. Véanse los siguientes pasajes de Krabbenhoft, 1994: «En la segunda parte de la Vida de Marco Bruto, Quevedo desarrolla ciertos tópicos introducidos en la primera parte, siguiendo el método de ordenación establecida en ella pero cambiando la forma y el contenido de la representación. Tiene en común con la primera parte el hecho de consistir en buena medida en textos traducidos con comentarios, y termina con una peroración o resumen de todo lo que precede. A diferencia de la primera parte, la segunda pasa de la representación de sucesos ocurridos en la antigüedad clásica a la época relativamente reciente de los Reyes Católicos. El argumento tiene como objetivo, como veremos más adelante, la comparación de las figuras protagonistas en dos conspiraciones muy dispares» (p. 32); «si miramos la secuencia de tópicos, vemos que hay continuación, consistencia, elaboración y desarrollo de tópicos ya planteados en las dos partes anteriores, tópicos que surgen en la tercera parte con nuevos significados y matices sin los que la historia de los Idus de marzo quedaría incompleta» (p. 34).

118. Véase, por ejemplo, Martinengo, 1998a, pp. 12, 23, 79-80, 96-97, 102-106.

119. Martinengo, 1998a, pp. 96-97. 
en forma cercana a las controversias y suasorias $^{120}$, tal y como se explicita en su epígrafe: «Pregúntase qué hiciera Julio César si antes de entrar en el Senado leyera el memorial que le dieron, declarándole la conjura y los nombres de los que entraban en ella» (p. 972). Con posterioridad a estas dos secciones, probablemente en fechas muy próximas a su edición, Quevedo habría añadido la traducción de las suasorias sexta y séptima de Séneca el retórico. Josette Riandiére (1976, p. 58) las consideró añadidos que acaso introducirían la segunda parte que preparaba Quevedo. Martinengo (1998a, p. 73) indicó que entre 1632 y 1639 Quevedo seguramente no habría podido volver sobre lo escrito al habérsele embargado el manuscrito de la obra junto a otros papeles suyos; para él, la parte escrita hasta entonces estaría constituida por las dos primeras secciones, y no por las «Suasorias», que se habrían añadido en fecha cercana la publicación por un problema derivado de la impresión: el quedar algunas hojas libres en el último pliego, algo no inhabitual en la imprenta de la época (Martinengo, 1998a, pp. 92-93) ${ }^{121}$.

Otra posibilidad es la que apuntó Michèle Gendreau (1977, pp. 231232), para quien la primera sección habría sido redactada en 1631 y las dos siguientes en torno a 1644. Para Alfonso Rey (2012, p. 53), el plan inicial de la obra podría haber comprendido la primera sección -la “Vida de Marco Bruto» con los discursos que la comentan-, y posteriormente se habría ampliado con las otras dos -la «Cuestión política» y las «Suasorias»-; esta posibilidad viene sugerida por la siguiente afirmación de Quevedo al comienzo de la obra: «Primera parte de la vida de Marco Bruto. Escribiola por el texto de Plutarco, ponderada con discursos, don Francisco de Quevedo Villegas» (p. 693). Finalmente, María José Alonso Veloso (2012, pp. 643-648) defiende que esa variedad estructural que ofrecen las tres secciones de la primera parte no debe implicar fases sucesivas en su redacción, y que toda la obra podría haber estado concluida en lo esencial en 1631, como Quevedo parece indicar en la dedicatoria "A quien leyere»: «Este libro tenía escrito ocho años antes de mi prisión; quedó con los demás papeles míos embargado y fueme restituido en mi libertad» (Primera parte de la vida de Marco Bruto, p. 721).

Aun teniendo en cuenta las diferencias que ofrecen los anteriores juicios sobre la estructura y el proceso de redacción de la obra, lo que sí coincide en todos ellos es el hecho de subrayar la variedad de las distintas secciones que la configuran. Una variedad que ofrece perspectivas diversas en torno a la lección política y moral que se extrae de la vida de Marco Bruto y, en concreto, de su actuación en la conjura contra César. No es, pues, una estructura compacta y unitaria al uso de las que hoy se

120. Controversias y suasorias son dos géneros retóricos escolares de gran auge en la etapa imperial romana: las controversias reproducían procesos imaginarios donde cada uno de los oradores sostenía una posición opuesta; las suasorias desarrollaban un debate imaginario ante el público.

121. Alonso Veloso, en Quevedo, Primera parte, pp. 646-647, discrepa de esta opinión por razones fundamentalmente bibliográficas. 
consideran coherentes o trabajadas, pero ese juicio no debe aplicarse al tiempo de Quevedo, donde la variedad que ofrecía la suma de partes sobre un motivo central era -como en la Edad Media y el siglo xvI- un tipo de organización habitual en muchos textos. Por otra parte, es difícil pronunciarse con rotundidad sobre esta cuestión al no conocer lo que habría sido esa segunda parte que no llegó a ver la luz. El análisis de la argumentación ofrece una variedad de recursos acorde con esa proteica organización del texto.

La primera sección -«Vida de Marco Bruto»-, recrea un género que proliferó en todo el Renacimiento y en España desde el siglo $\mathrm{xv}$, las «Vidas de hombres ilustres». Estas seguían los modelos romanos de Suetonio (Vidas de los doce Césares) y Tito Livio (Historias), y los griegos de Plutarco (Vidas paralelas), Filóstrato (Vidas de los sofistas) y Diógenes Laercio (Vidas, opiniones y sentencias de los filósofos ilustres) ${ }^{122}$. En relación con Quevedo deben destacarse las tres biografías con trasfondo político escritas por Virgilio Malvezzi y dedicadas a Rómulo y Tarquino el Soberbio - primer y último reyes de Roma- y al rey David. Como es sabido, Quevedo traduciría del italiano la primera de las citadas (Il Romolo) en $1632^{123}$. Las Vidas de Juan Pablo Mártir Rizo también deben ser destacadas por la afinidad entre su autor y Quevedo ${ }^{124}$.

La sección “Vida de Marco Bruto» se divide en treinta secuencias de «Texto»y «Discurso». Quevedo traduce el texto de Plutarco y lo acompaña de su comentario en el «Discurso» ${ }^{125}$. Técnicamente, la disposición de estos modelos se asemeja a la de obras como Política de Dios o el Job ${ }^{126}$. Si en Política de Dios el texto bíblico actuaba como exemplum cuya analogía política se desarrollaba en el comentario de Quevedo, en Marco Bruto sucede algo similar con el texto de Plutarco, del que se extrae la enseñanza política y moral que se desarrolla en los «Discursos».

Como también sucedía en las obras antes analizadas, la argumentación de esta sección del Marco Bruto sigue teniendo en el estilo un cauce fundamental para la persuasión. La paradoja y el oxímoron, apoyados

122. Véanse, entre otros, Civil, 1998; Schwartz, 2005, 2007; Gómez Moreno, 1994, pp. 227-241; Momigliano, 1971; Vaíllo, 2007, pp. 23-31.

123. Sobre Malvezzi y Quevedo, véase el trabajo de Blanco, 2004.

124. Las estudiaron Civil, 1998; Schwartz, 2005, 2007. Jauralde, 1998, pp. 499-554, y 558-562, señaló la admiración de Mártir Rizo por Quevedo y la coincidencia de intereses literarios entre ambos, así como la defensa que Mártir Rizo hizo de Quevedo ante los escritos de Morovelli. Las vidas publicadas por Mártir Rizo fueron las de Séneca (1625), Mecenas (1626), el Duque de Birón (1629) y Rómulo (1633).

125. Sobre posibles ediciones de Plutarco manejadas por Quevedo, véase Martinengo, 1998a, p 13. No entro en la trillada cuestión de los conocimientos de Quevedo sobre distintas lenguas y su pericia como traductor. No debían de ser tan deficientes si era capaz de adaptar las fuentes a su argumentación.

126. Como se ha indicado, esta conexión en la esfera del comentario también guarda relación con la exégesis tropológica, que consistía en asociar a los motivos de las escrituras una máxima moral. Blanco, 1992, pp. 520-522, agrupa varias obras de Quevedo sobre este principio de la exégesis sacra y profana: Marco Bruto, La constancia y paciencia del santo Job, La caída para levantarse..., Política de Dios. 
por la sentenciosidad y el paralelismo antitético son, junto a la metáfora, los recursos más destacados.

La importancia y finalidades de paradoja y oxímoron fueron ya estudiadas en el clásico trabajo de Roig Miranda (1980). Su presencia resulta lógica en una obra donde se relativizan los valores morales y se contrastan con las duras exigencias de la práctica política ${ }^{127}$, y donde el sistema de valores del mundo contrasta con su inversión en la cosmovisión cristiana. Señalo dos ejemplos donde transmite los peligros que esconde la adulación:

Solamente los hechiceros de la ambición pudieron confeccionar corona que quitase corona, honra que atosigase honra, vida que envenenase la vida, adoración que produjese el desprecio, aplauso que granjease odio (Primera parte de la vida de Marco Bruto, p. 794).

Humillábanse éstos a César para derribarle; llegábanse a él para apartarle de la vida; llevábanle en los abrazos las heridas, y en los besos la ceguera (Primera parte de la vida de Marco Bruto, p. 853).

En ese marco de contradicciones y disimulo, la antítesis resulta fundamental en el contraste de buenos y malos comportamientos ${ }^{128}$. Destaca también una figura ya observada en las obras históricas: la correctio. Se utiliza, bien para lograr un encarecimiento expresivo que intensifica la alabanza o vituperio de los personajes, bien para matizar muchos de sus actos, algo muy importante en una obra presidida por el relativismo de lo moral. Así sucede en los dos siguientes ejemplos; en el primero, Casio intenta precisar en sus palabras a los demás conjurados la intención de su intento; en el segundo, se subraya la censura del tirano:

Yo no tengo enemistad con la persona de César, sino con su intento, ni en estas palabras oís mi venganza, sino mi celo (Primera parte de la vida de Marco Bruto, p. 799).

Tirano es aquel príncipe que, siéndolo, quita la comodidad a la paz y la gloria a la guerra, a sus vasallos las mujeres y a los hombres las vidas; que obedece al apetito, y no a la razón; que afecta con la crueldad ser aborrecido, y no amado (Primera parte de la vida de Marco Bruto, p. 894).

Esa idea de mundo al revés, plagado de falsas intenciones y circunstancias cambiantes en la política y las conductas, la logra transmitir

127. Véase Blanco, 1992, pp. 577-583, para estas relaciones entre las esferas política y moral.

128. Para el paralelismo sentencioso y la antítesis, véase Azaustre, 1996, pp. 171-176 y 246-250; se señalan allí sus efectos en la transmisión del mensaje o, lo que es lo mismo, su papel argumentativo. Alonso Veloso, 2013, pp. 100-114, lo aborda en las orationes incluidas en el Marco Bruto. Sobre la paradoja y su uso y significado en Marco Bruto en la esfera del conceptismo, véase Blanco, 1992, pp. 527-538, quien destacó la conexión entre el estilo sentencioso y conceptista de Quevedo y el relativismo de los valores morales que se manifiesta en el Marco Bruto (Blanco, 1992, pp. 523-526). 
Quevedo de manera muy eficaz mediante simétricos quiasmos y commutationes. Señalo dos pasajes vinculados a la comparación entre diversos personajes de la obra:

A lo primero, digo que Marco Antonio sabía ejecutar bien lo que pensaba mal, y Marco Bruto ejecutaba mal lo que pensaba bien (Primera parte de la vida de Marco Bruto, p. 887).

Brevemente lo repetiré: fue, pues, que Junio Bruto empezó tonto y acabó sabio; y Marco Bruto empezó sabio y acabó tonto (Primera parte de la vida de Marco Bruto, p. 895).

En combinación con los anteriores recursos, Quevedo recurre con bastante frecuencia a los juegos de palabras (políptoton, derivatio, paronomasia...) como expresivo traslado lingüístico de los recovecos, cautelas y escondidas intenciones que encierra la actuación política, o bien de la complejidad de los comportamientos por la convivencia del bien y el mal en el individuo:

Pocas veces son dichosos los avisos saludables en poder de los tiranos; no es nuevo en ellos tomar el buen advertimiento para olvidarle, ni poco antiguo perderse por haberle olvidado. Canas tiene el divertir a los príncipes para que no lean lo que les importa. Faltole tiempo a César para leer, y faltole la vida por no haber leído. Justo es que quien difiere a otro tiempo su remedio no alcance remedio ni tiempo (Primera parte de la vida de Marco Bruto, p. 844).

El robo que saquea las repúblicas es aquel que, hipócrita de la codicia, llama desinterés el no recibir de otro, y limpieza el tomarlo todo. No tomar del que puede dar, por tomarle el poder, para tomarse lo que quisieren y no pedir, es, con buen nombre, escalamiento del poder (Primera parte de la vida de Marco Bruto, p. 871)

Por lo que respecta al laconismo y la sentenciosidad, el propio Quevedo subraya la brevedad de su estilo en varios lugares al comienzo del Marco Bruto; una brevedad que, según el texto de Plutarco, era propia del discurso de Marco Bruto ${ }^{129}$ :

Poco escribo, no porque escuso palabras, sino porque las aprovecho y deseo que hable la dotrina a costa de mi ostentación. Aquel calla que escribe lo que nadie lee, y es peor que el silencio escribir lo que no puede acabarse de

129. Así se observa en la traducción del texto de Plutarco: «Fue Marco Bruto en la lengua latina bien acomodado al estilo militar y cortesano; en la griega, con dicha afectó la brevedad lacónica. Prueban esta sentenciosa concisión sus cartas, donde pocas palabras dan luz a grandes discursos, sin que el letor eche menos lo que falta ni deje de leer lo que no está escrito. Lo poco en sus epístolas parece que sobra, y lo que sobrara en otro no parece que falta en él. Usó de las palabras como de la moneda: razonaba oro y no metal bajo; valía una razón ciento. iTantos quilates subía su lenguaje!) (Primera parte de la vida de Marco Bruto, p. 739). 
leer; y más reprehensible acabar de escribir lo que cualquiera se arrepiente de acabar de leer.

De mí sólo aseguro que ni el que me empezare a leer se cansará mucho ni el que me acabare de leer se arrepentirá tarde. Harto haré si alcanzo a parecer bueno por poco malo, y aun esta disculpa tan culpable no se deberá a mi ingenio, sino a mi brevedad, no imitando a aquellos que ponen su cuidado en no empezar a decir sin acabar de hablar (Primera parte de la vida de Marco Bruto, pp. 720-721).

Era apacible al pueblo su vida [de Marco Bruto], y a los padres agradable su conversación y el estilo de sus escritos, en que ni él se cansaba ni cansaba; al revés de muchos que ponen la elegancia en no empezar a decir ni acabar de hablar (Primera parte de la vida de Marco Bruto, p. 742).

Como él mismo manifiesta, Quevedo prefiere un estilo «preñado» donde lo fundamental sea la riqueza de contenidos que encierra ese breve discurso. Era, según Gracián, el estilo propio de los filósofos morales (Agudeza y arte de ingenio, Discurso LXI). Como ya se ha indicado, ese laconismo transmite las ideas y advertencias con la fuerza y la solemnidad de la sentencia: los miembros sentenciosos de este estilo «dan gran energía a consejos y amonestaciones morales. De esta forma quedan grabados como una sucesión de máximas destacadas por su simetría», y «su fuerza expresiva contribuye a la persuasión afectiva» ${ }^{130}$.

En cuanto a la metáfora, vuelve a alcanzar en Marco Bruto la notoriedad que se observó en Grandes anales, Mundo caduco o Política de $\operatorname{Dios}^{131}$. Lo hace tanto en la esfera política común a aquellas obras como en la puramente moral. Uno de los mejores ejemplos lo constituye el arranque del discurso veinticinco, donde paradoja y metáfora retratan la naturaleza sigilosa y disimulada del pecado. Otro acumula diversas metáforas relacionadas con la necesidad de prudencia y secreto ante las grandes acciones $^{132}$ :

No hay cosa tan disimulada como el pecado: en la noche que le sobra, con que ciega sus fines, escurece los sentidos y potencias de sus secuaces. Es lumbre de linterna, que turba y deslumbra a quien la mira y pone en ella los ojos; es luciérnaga, que, mirada de lejos, se juzga estrella y, acercándose y asiéndola, se halla gusano que se enciende en resplandor con la obscuridad y se apaga con la luz (Primera parte de la vida de Marco Bruto, p. 857).

Las determinaciones grandes quieren que prevenga la prudencia propia a la malicia ajena. Hase de poner en el alma tan estrecha reclusión a los

130. Azaustre, 1996, pp. 246-247. Para los modelos de esta sintaxis lacónica, véanse las pp. 187-195.

131. Vaíllo, 1998, pp. 393-398, estudió en detalle varias de las más destacadas en el Marco Bruto, y subrayó su construcción sobre proporciones matemáticas (véase también Vaíllo, 2000, p. 402). Rey, 2012, pp. 80-83, destacó su importancia en esta obra.

132. Véanse también, entre otros muchos ejemplos, las alegorías referentes a la monarquía del sol (pp. 771-774) y el cuerpo del reino (pp. 795-796). Más detalles en Martinengo, 1998a, p. 35, y Vaíllo, 2000. 
pensamientos que no se les deje salida ni respiradero desde los sentidos a las potencias. Son parleros los ojos, y suelen las acciones del cuerpo ser chismes de la negociación del entendimiento [...] La hipocresía exterior, siendo pecado en lo moral, es grande virtud política; llámola el viento de que se sustenta el camaleón del poder (Primera parte de la vida de Marco Bruto, p. 827).

También la metonimia resulta de gran eficacia para manifestar de forma gráfica intenciones y conductas al ser expresadas mediante realidades o acciones concretas. En el primer ejemplo se observa un uso ya señalado en Política de Dios: la metonimia expresa cualidades intelectuales o del espíritu mediante las partes del cuerpo que las albergan y las transmite así con más vigor; en este caso se trata de la proverbial advertencia a los reyes sobre los peligros de la adulación. En el segundo, que versa sobre el mismo asunto, se encadenan varias metonimias (abrazos, estoques, puñalada, caricias) que, junto a la paradoja, muestran de forma concreta y evidente los peligros de la adulación que precedió al asesinato de César, y se combinan con agudas metáforas (matador invisible, tienda de todos los aparatos del engaño) que la definen:

iOh monarcas! Desembarazad las orejas de los que os las muerden y no os las hablan, y sólo os las sueltan sus bocas para despedazar y tragarse el consejo que viene a ellas (Primera parte de la vida de Marco Bruto, p. 793) ${ }^{133}$.

Los que para hacerle aborrecible le añadieron corona, dignidad y poder para matarle le prendieron con la adoración, le cercaron con reverencias y le cegaron con los besos. Más homicidas fueron aquí los abrazos que los estoques. Debo decir que sin aquéllos no lo supieran ser éstos. Bien puede haber puñalada sin lisonja, mas pocas veces hay lisonja sin puñalada. Pocos tienen a la adulación por arma ofensiva, y menos los que no la padecen. Es matador invisible a la guarda de los monarcas: éntrales la muerte por los oídos, envainada en palabras halagüeñas. Las caricias en los palacios hacen traiciones y traidores, y cuando son menos malas, son prólogos de la disimulación. Tan desnuda anduviera la mentira como la verdad, si la lisonja no la vistiera de todas colores. Es la tienda de todos los aparatos del engaño, de todos los trastos de la maldad. En ella halla espadas la ira, máscaras el enojo, caras la traición, novedades el embeleco, disfraces la asechanza, joyas el soborno, galas y rebozos la ambición, la maldad puestos, y la infamia caudal (Primera parte de la vida de Marco Bruto, pp. 852-853).

Junto a estos recursos de estilo cabe señalar la importancia de los ocho discursos u orationes de los personajes, de los que la crítica se ha ocupado en profundidad ${ }^{134}$. Como ya se ha señalado, es este un rasgo clásico en la historiografía -véase lo dicho a propósito de Grandes anales-

133. Alonso Veloso, en Quevedo, Primera parte, p. 793, n. 486, señala ejemplos de este tópico uso de la metonimia referida a la oreja del príncipe.

134. Para las orationes del Marco Bruto, véanse Krabbenhoft, 1994, pp. 26-32; Martinengo, 1998b; Nider, 2007, pp. 269-287; 2010 y 2011; Alonso Veloso, 2013, pp. 91-100. 
y, concretamente, en el género de las Vidas ${ }^{135}$. Su función retórica está próxima a la sermocinatio, uno de los cauces que la evidentia usaba para poner ante los ojos las acciones y hechos, en este caso mediante el discurso directo. Quevedo dominaba esta cualidad del estilo, sobre la que mostró un gran interés atestiguado en varios escritos y anotaciones ${ }^{136}$. En Marco Bruto, esos discursos cumplen una doble moción de afectos, que se bifurca entre los personajes que los escuchan dentro de la obra y sus lectores. A esa impresión de vida contribuye también la inserción de una carta apócrifa de Bruto a Cicerón, cuidadamente elaborada por Quevedo para perfilar el carácter del personaje ${ }^{137}$. En varias ocasiones, Quevedo añade al final de esas orationes un pasaje donde muestra la reacción de los destinatarios y la influencia (mouere) que se logra en sus afectos; la variedad de reacciones (ternura, fervor, ira) es una inmejorable prueba de la capacidad persuasiva de estos parlamentos, que se incrementa cuando el receptor es el siempre voluble pueblo:

Oyola Bruto y, mezclando sus lágrimas con su sangre, pagó su valentía comunicándola el intento que la callaba, y de justicia debía a su muerte (Primera parte de la vida de Marco Bruto, p. 821).

Oyola Bruto con toda la alma y, compitiéndola en el semblante lo mortal, procuraba con suspiros sostituir la vida a Porcia, y se enterneció humanamente en la piedad de oficio tan lastimoso (Primera parte de la vida de Marco Bruto, p. 822).

Siguió estas palabras un largo aplauso de la gente, y con voces agradecidas le pidieron que se viniese con ellos a gozar por la ciudad las alabanzas que merecía (Primera parte de la vida de Marco Bruto, p. 863).

Serenó este razonamiento los ánimos, de suerte que, fervorosos, pasaron de la ira al agradecimiento $\mathrm{y}$, llamándole padre de la patria, pedían que a Bruto y a los suyos fuesen concedidos honores y dedicadas estatuas (Primera parte de la vida de Marco Bruto, p. 864).

Junto a estas orationes cabe señalar otros casos que consisten en breves parlamentos de un personaje que se insertan en la narración. A la ya mencionada fuerza expresiva se une en algún caso otro clásico recurso de la evidentia, el mostrar las heridas o ropas ensangrentadas:

135. Lo han señalado, entre otros, Civil, 1998, p. 370; Schwartz, 2005, p. 100, y 2007 , p. 169; Nider, 2011.

136. Se ocupó de la evidentia en la dedicatoria a Olivares que precede a su edición de las poesías de fray Luis de León; anotó en su ejemplar de la Retórica de Aristóteles algunos pasajes referidos a ella, y anotó en su ejemplar del poema épico Eracleide, de Gabriele Zinano, varios lugares donde se presentaban descripciones: una de ellas mostraba vivamente el movimiento del caballo, uno de los clásicos ejemplos de evidentia. Finalmente, en su sección «Del estilo» del Job, Quevedo alabó la evidente descripción que del caballo se hacía en este libro bíblico (Job, 39, 19-25). Más detalles y bibliografía en Azaustre, 2003.

137. Martinengo, 1998a, p 71, ha mostrado cómo Quevedo la compuso taraceando diversos fragmentos de Plutarco, cuidadosamente seleccionados para retratar a Marco Bruto como enemigo de la tiranía, no del tirano. 
$\mathrm{Y}$ viendo Antonio con estas palabras precipitada la ciudad a las honras del difunto y al castigo de los malhechores, sacando la vestidura de César, que traía consigo, llena de sangre y horrible con las muchas heridas, descogiéndola al pueblo, añadió tales razones: «Ésta es la toga que en César fue venerable y en mis manos es horror escandaloso; en ella sus venas, que fueron aclamación del mundo, son manchas: no permitáis que se pasen a vuestra honra». No lo hubo dicho, cuando, echando en la hoguera las cátedras y las sillas de los templos y de los tribunales y cuanto hallaron precioso, la encendieron; y luego que emprendió la llama, tomando tizones y maderos encendidos della, con furia popular corrieron a poner fuego a las casas de los conjurados (Primera parte de la vida de Marco Bruto, p. 878).

Como último rasgo destacable en la argumentación quevediana, cabe señalar la propia traducción del texto de Plutarco. Alessandro Martinengo (1998a, pp. 25-78) demostró cómo las constantes amplificaciones y omisiones que Quevedo lleva a cabo sobre su fuente fueron cuidadosamente concebidas para enlazar ese texto con la reflexión que Quevedo propone en su discurso ${ }^{138}$. La libertad en la traducción, concebida como un modo libre de imitatio, es un fenómeno estudiado por la crítica ${ }^{139}$. A ello se une aquí una manipulación argumentativa que ya se observaba en Política de Dios, cuando Quevedo buscaba en el texto bíblico los lugares y analogías que mejor se adecuaban a su razonamiento. Como sucede con la clásica fragmentación interesada de la cita, la traducción y hasta la collatio de variantes se convierten en recursos de persuasión retórica.

La segunda sección de la obra se titula «Cuestión política» ${ }^{140}$. Plantea una disyuntiva que se enuncia en su epígrafe: «Pregúntase qué hiciera Julio César si, antes de entrar en el Senado, leyera el memorial que le dieron, declarándole la conjura y los nombres de los que entraban en ella» (p. 897). El recurso fundamental en la argumentación de esta sección es el exemplum. Para responder a la anterior cuestión, Quevedo incluye primero el ejemplo cercano de Fernando el Católico, quien, advertido de la amenaza que para él suponía el Gran Capitán, obró con disimulo mediante la alabanza y el alejamiento estratégicos. El ejemplo de Fernando el Católico se enriquece con diversas cartas inéditas que aporta Quevedo, las cuales refuerzan su enseñanza con el peso de las pruebas inartificiales (praeiudicia). Tras el ejemplo del monarca hispano, Quevedo inicia una parte cercana al esquema retórico de la suasoria y la controversia, pues explora las diferentes opciones que habría

138. Estudios como los de Riandière, 1976; Gendreau, 1977; Roig Miranda, 1980, y Peraita, 1996, también señalaron la intervención de Quevedo sobre sus modelos para adaptarlos a sus propósitos. Martinengo, 1998b, p. 415, analizó los intencionados retoques de Quevedo sobre su fuente en el episodio de la muerte de Porcia, donde «alterna, consciente y desenvueltamente, para mejor conseguir los efectos de persuasión retórica que se propone, procedimientos narrativos per amplificationem y procedimientos per detractionems.

139. Véanse, por ejemplo, Copeland, 1991, pp. 9-36; López Grigera, 1998, pp. 54-55; Plata Parga, 2001, pp. 214-216.

140. Véase el análisis que de ella hace Martinengo, 1998a, pp. 79-90. 
podido adoptar Julio César de haber leído el memorial. Valora así las posibilidades extremas - actuar en venganza y matar a los conjurados o disimular como Fernando el Católico- y concluye con la que escogió Bruto: dejarse matar para así matar la conjura. Para concluir esta sección, Quevedo incluye una galería de ejemplos históricos de príncipes y poderosos que se enfrentaron a rebeldes y conjuraciones: algunos inclinados a la disimulación; otros, a la acción. Estos ejemplos se toman de auctoritates que apoyan su lección, y en ocasiones su relato se enriquece con la inserción de breves frases de sus protagonistas en estilo directo, lo que contribuye a poner ante los ojos dicha enseñanza con la fuerza ya señalada para las orationes. Entre estos exempla se incluye al duque de Osuna, reivindicando así Quevedo, al final de su vida, su decidida actuación en Italia, y recordando el valor que había concedido a la experiencia propia en sus obras históricas.

La “Cuestión política», en conjunto, amplifica la biografía comentada de Marco Bruto con una reflexión que, bajo un esquema retórico próximo a suasorias y controversias, explora las distintas posibilidades de actuación del monarca ante una conjura. A la complejidad y relativismo que ofrece esa perspectiva de la controversia se añaden la riqueza y autoridad del exemplum y las auctoritates. Aquí, además, debe destacarse la deliberada inclusión de casos contemporáneos -Fernando el Católico y el duque de Osuna- junto a la galería de personajes históricos, rasgo que ya se avanzaba en los preliminares de la obra. El recurso enriquece notablemente el juego de perspectivas y establece un diálogo con la historia en un sentido diferente del habitual ${ }^{141}$.

La última parte del Marco Bruto la constituye la controvertida traducción de las suasorias sexta y séptima de Séneca el retórico, de las que ya se ha mencionado el problema de su integración en el conjunto de la obra. Las «Suasorias» vuelven a mostrar ese variado juego de enfoques y perspectivas desde los que Quevedo aborda los complejos dilemas políticos y morales que tienen como eje la vida y el tiempo de Marco Bruto.

El análisis de las suasorias revela, en primer lugar, el ejercicio retórico de un escritor que deseó medirse en diversos géneros. La suasoria era un género retórico consistente en una discusión sobre lo que debía o no hacerse en una determinada situación. Quevedo realizó otras tentativas en este terreno, pues afirmaba al final de la "Cuestión política» haber traducido todas las controversias de Séneca, y algunas de ellas han sido descubiertas y editadas por Fernando Plata (2001). La controversia era un género cercano a la suasoria, aunque más fiel al esquema de un caso judicial imaginario ${ }^{142}$.

En la primera suasoria se discute si Cicerón debía rogar o no por su vida a Marco Antonio. Quevedo traduce el texto de Séneca, donde se

141. Véanse al respecto, Krabbenhoft, 1994, p. 24, y Martinengo, 1998a, p. 80, n. 100.

142. Recuérdese que, en el Job, Quevedo aprovechó el esquema de pleito que el libro bíblico propiciaba en la conversación del santo con sus amigos. Sobre la recreación quevediana del modelo de las controversias de Séneca, véase Adiego-Artigas-Riquer, 2009. 
repasaba la opinión de diversos oradores romanos, todos ellos favorables a que Cicerón muriese antes que suplicar al tirano. La vehemencia y la solemne sentenciosidad caracterizan sus intervenciones; junto a ellas cabe destacar la galería de exempla de hombres ilustres por morir dignamente, y la paradoja que traduce la doblez y complejidad innatas a los comportamientos políticos. A estas opiniones (o colores) ${ }^{143}$ se añade la del propio Quevedo que, de forma más extensa, se incorpora a esa galería de antiguos oradores recomendando la misma opción; su afán por aportar algo nuevo a los recursos oratorios usados por aquellos se muestra en la incorporación a su argumentación de varios pasajes de cartas de Cicerón.

Mayor complejidad ofrece la organización de la séptima suasoria, donde se discute si Cicerón debería quemar sus escritos ante la promesa de Marco Antonio de perdonarle la vida si lo hacía. La suasoria de Séneca recogía las opiniones de diversos oradores que defendían la muerte de Cicerón y la vida de sus escritos. Quevedo completa la discusión retórica con un discurso donde defiende la opinión contraria para así ofrecer las dos posturas o colores posibles: es una clara muestra de su interés en recrear todas las posibilidades de este género oratorio. $\mathrm{Al}$ oponerse Quevedo a esta galería de oradores, muestra además su gusto por la refutatio, patente ya desde su temprana España defendida, y que parece lógica en un escritor definido por su talante satírico. Quevedo se incorpora así a la galería de antiguos oradores enriqueciendo una vez más el juego de perspectivas y mostrando un diálogo con la historia semejante al que construyó con los ejemplos en la «Cuestión política».

En una nota que precede a su intervención en la disputa, Quevedo apoya esta en una conjetura de la edición de las controversias de Séneca preparada por Andreas Schott, donde este humanista prefería la lectura nulla pars a illa pars en la frase «cum adeo illa pars non sit mala», dando a entender así la licitud de las dos posturas ante el dilema que se planteaba a Cicerón ${ }^{144}$. El detalle muestra una vez más cómo Quevedo adecua las fuentes a sus ideas e intereses. Si en otras ocasiones eran la analogía bíblica o la traducción de Plutarco, ahora se llega a la collatio de variantes para construir argumentativamente sobre ella una parte del texto.

143. En retórica el término color puede referirse a los tropos y figuras que contribuyen al ornatus (Cicerón, Brutus, 87, 298; De oratore, 3, 25, 100); pero aquí se entiende en su otra acepción, la del retoque interesado en la presentación de la causa cuando esta resulta de compleja defensa (Quintiliano, Institutio Oratoria, 4, 2, 88). El nombre color proviene de la alegoría que considera el discurso como una pintura cuyos colores pueden matizarse. En las controversias -y, por influencia de estas, en algunas suasorias-, se denominan colores esas estrategias que se proponen para la actuación ante el caso o problema concreto. Véanse también Lausberg, 1984, §§ 329, 1061, y Alonso Veloso, en Quevedo, Primera parte, p. 975 , n. 1298 a 1300.

144. Sigo a interpretación de Martinengo, 1998a, pp. 99-102, quien corrige las observaciones de González de la Calle, 1965, pp. 51-57. 
En la parte final de la suasoria, Quevedo construye la respuesta de Cicerón ante ambas opiniones ${ }^{145}$. Se trata de un rasgo innovador sobre el esquema de la suasoria, innovación que Quevedo parece también haber procurado en su recreación de las controversias de Séneca el Retórico. La modificación sobre el modelo de las suasorias se hallaría en la intervención final de Cicerón rechazando el dilema que se planteaba $^{146}$; por lo que atañe a las controversias, en el hecho de añadir una decisión y sentencia.

Junto a su valor como ejercicio retórico, cabe señalar la posible interpretación autobiográfica que propone una analogía por la que Cicerón y Marco Antonio corresponderían a las figuras de Quevedo y Olivares ${ }^{147}$. Las implicaciones de este planteamiento biográfico son evidentes a la luz del asunto de las controversias; además de insistir en el clásico tema de las relaciones entre el escritor y el privado, muestran la valoración de Quevedo sobre el conjunto de su obra. Si los discursos de Quevedo en estas suasorias hubiesen sido redactados en san Marcos ${ }^{148}$, constituirían además una afirmación del valor de su obra como testimonio de una vida en la estela del tópico tradicional de la fama.

Junto a estas posibles implicaciones biográficas, el recurso al caso de Cicerón y Marco Antonio muestra de nuevo el ingenioso manejo de la analogía en Quevedo. Su proverbial dominio de la agudeza no solo en el terreno de tropos y figuras, sino para traer ejemplos históricos o bíblicos a su tiempo, o incluso para retrotraer al pasado los casos contemporáneos, como hizo con Fernando el Católico en la «Cuestión política», o como hace con su propia pluma añadida a la de los oradores romanos. Se trata, en fin, del dominio de la «agudeza» que Gracián estudió en los discursos lv a LVII de su Agudeza y arte de ingenio ${ }^{149}$.

Toda esta riqueza argumentativa es lógico correlato de la complejidad ideológica del Marco Bruto, que no es posible abordar aquí. Concebida como colofón a su literatura doctrinal, Quevedo reúne las

145. Para Martinengo, 1998a, pp. 102-106, se observa aquí una rehabilitación de la figura de Cicerón, que había sido tildado de cobarde en la «Vida de Marco Bruto».

146. Adiego-Artigas-Riquer, 2009, pp. 141-144, subrayan que este rechazo de Cicerón a tomar partido no respeta el molde retórico de la suasoria, donde el orador solía tomar partido por una de las posturas enfrentadas. Para Nider, 2010a, p. 331, puede significar que Quevedo hubiese ensayado el género retórico de la prosopopeya, difundido como ejercicio escolar y académico en el que se declamaban piezas oratorias ficticias puestas en boca de personajes ilustres. 106.

147. Véanse Gendreau, 1977, pp. 370-372; Martinengo, 1998a, pp. 94-95, 103, 105-

148. Las traducciones de las suasorias son posteriores a 1633 , fecha en la que parece haber comenzado a usar la edición parisina de Schott; véanse Gendreau, 1977, pp. 362364, y Martinengo, 1998a, pp. 93-94. Plata, 2001, pp. 211-212, ha estudiado las ediciones de Schott de las que pudo haberse servido Quevedo en su traducción de las controversias de Séneca.

149. Véase además Blanco, 1992, para la importancia de la agudeza en la preceptiva europea del xviI; sobre estas obras doctrinales de Quevedo, véanse sobre todo las pp. 520-536. 
esferas política, moral y acaso también autobiográfica en una profunda reflexión que, partiendo de un ejemplo histórico (o biografía ejemplar, si se prefiere), se proyecta a cuestiones como la licitud del tiranicidio, los peligros que acechan al monarca, la conveniencia de la acción o la disimulación en el gobierno, o las siempre controvertidas relaciones con Olivares; en una dimensión más amplia, el texto examina las consecuencias del pecado, el destino marcado por la Providencia, el peso de la conciencia y la doblez del alma humana, donde virtud y maldad conviven en imposible armonía ${ }^{150}$. Quevedo ya había tratado todas ellas a lo largo de su prosa doctrinal, pero el Marco Bruto parece concebido como una síntesis que las lleva a su máxima expresión.

\section{Conclusión}

Este repaso de algunas obras políticas de Quevedo constata la habilidad y riqueza de su argumentación. En ella destacan su preferencia por la persuasión afectiva y el uso argumentativo de los recursos de estilo y de la erudición que proporcionan citas, ejemplos o traducciones. Quevedo prefiere apelar a los afectos de sus lectores, pues su talante satírico es más dado a una censura que no casa tan bien con la abstracción silogística. En Grandes anales y Mundo caduco, donde recrea la actualidad histórica de España y Europa, utiliza interesadamente su perspectiva de testigo, selecciona los hechos que relata y omite, y trabaja los resortes del estilo -en especial la sentenciosidad, la metáfora y la moción de afectos de las orationes - para orientar el relato histórico hacia su posición política; esto es, argumenta sobre la historia. Cuando construye Política de Dios y Marco Bruto sobre el texto bíblico y el relato de Plutarco, traduce intencionadamente, busca entre las versiones bíblicas la variante que mejor casa en su razonamiento, traslada ejemplos contemporáneos como modelos al pasado, o encuentra brillantes analogías entre las más diversas fuentes y documentos. El ingenio y el dominio de la agudeza construyen esa peculiar argumentación, bastante denostada por la ortodoxia de su tiempo. Esta agudeza de Quevedo fue censurada por exégetas, legisladores e historiadores que lo acusaban de manejar lugares bíblicos y fuentes clásicas e históricas rompiendo el decoro de géneros y asuntos. No es, en el fondo, algo muy distinto de lo que el mismo Quevedo censuró a Góngora en cuestiones de estilo. Suele suceder cuando un escritor aplica su talento a los modelos establecidos, y resulta incluso justo que el 'clásico' Quevedo haya padecido la misma medicina que aplicó a los renovadores del estilo poético. Por algo las gramáticas convertían los vicios del lenguaje en licencias para el poeta, y las poéticas recomendaban a estos mesura y decoro al manejarlas. Metido en harina política, el poeta Quevedo unió al peso de las tradicionales probationes retóricas todo el caudal de recursos literarios que

150. Estas implicaciones de índole moral fueron subrayadas por Martinengo, 1998a, pp. $21-22,33,77$. 
albergaba la retórica y que su talento manejaba con pericia. No olvidó, en fin, que el ornatus no solo era una virtud que embellecía el discurso, sino también un poderoso elemento de persuasión. La argumentación de estas obras políticas muestra así un semblante variado precisamente por incorporar a sus clásicos recursos el talento literario de Quevedo.

\section{Bibliografía}

Adiego, Ignacio-Javier, Esther Artigas y Alejandra de Riquer, «Séneca el Viejo y Quevedom, La Perinola, 13, 2009, pp. 135-147.

Aftonio, véase Teón.

Alonso Veloso, María José, «La estructura retórica del Memorial por el Patronato de Santiago de Francisco de Quevedom, Bulletin of Spanish Studies, Lxxix, 4, 2002, pp. 447-463.

Alonso Veloso, María José, «La dispositio de Su espada por Santiago, de Francisco de Quevedo: una arriesgada apuesta por la refutación», en Actas del XIV Congreso de la Asociación Internacional de Hispanistas, Newark / Delaware, Juan de la Cuesta, 2004, pp. 27-34.

Alonso Veloso, María José, “Las "oraciones" en el Marco Bruto de Quevedo: modelos y construcción retórica», en Italia en la obra de Quevedo, eds. María José Alonso Veloso y Alfonso Rey, Santiago de Compostela, usc Editora, 2013, pp. 91-122.

Anscombre, Jean Claude y Oswald Ducrot, La argumentación en la lengua, trad. Julia Sevilla Muñoz y Marta Tordesillas, Madrid, Gredos, 1994 ( $1^{\mathrm{a}}$ edición, Lieja, 1983).

Aragüés Aldaz, José, Deus Concionator. Mundo predicado y retórica del exemplum en los Siglos de Oro, Amsterdam, Rodopi, 1999.

Arellano, Ignacio, Poesía satírico burlesca de Quevedo. Estudio y anotación filológica de los sonetos, Madrid / Frankfurt, Iberoamericana / Vervuert, 2003.

Aristóteles, Retórica, ed. bilingüe (griego-castellano) de Antonio Tovar, Madrid, Instituto de Estudios Políticos, 1971.

Aristóteles, Retórica, ed. Quintín Racionero, Madrid, Gredos, 1990.

Austin, John Langshaw, Cómo hacer cosas con palabras, Barcelona, Paidós, 1982 (1 a edición, 1962).

Azaustre Galiana, Antonio, Paralelismo y sintaxis del estilo en la prosa de Quevedo, Santiago de Compostela, Universidad, 1996.

Azaustre Galiana, Antonio, “Técnicas de argumentación retórica en Su espada por Santiago, de Francisco de Quevedo», Criticón, 71, 1997, pp. 105-115.

Azaustre Galiana, Antonio, «La argumentación retórica en el Memorial por el patronato de Santiago, de Francisco de Quevedo", Edad de Oro, xix, 2000, pp. 29-64.

Azaustre Galiana, Antonio, "Algunas influencias de la oratoria sagrada en la prosa de Quevedo», Criticón, 84-85, 2002, pp. 189-216.

Azaustre Galiana, Antonio, “Cuestiones de poética y retórica en los preliminares de Quevedo a las poesías de fray Luis de León», La Perinola, 7, 2003, pp. 61-102.

Azaustre Galiana, Antonio, «Estructura y argumentación del Lince de Italia u zahorí español de Quevedom, La Perinola, 8, 2004a, pp. 49-75. 
Azaustre Galiana, Antonio, «El comentario de la letra sagrada en Política de Dios,, en Studies in Honor of James O. Crosby, ed. Lía Schwartz, Newark / Delaware, Juan de la Cuesta, 2004b, pp. 23-49.

Azaustre Galiana, Antonio, «Estructura y argumentación de España defendida, de Francisco de Quevedo", Bulletin Hispanique, 114, 1, 2012, pp. 117-152.

Azaustre, Antonio, y Juan Casas, Manual de retórica española, Barcelona, Ariel, 2015 ( $1^{\text {a }}$ edición, 1997).

Biblia Sacra iuxta Vulgatam Clementinam, ed. Alberto Colunga y Laurentio Turrado, Madrid, Biblioteca de Autores Cristianos, 1985.

Blair, J. Anthony y Ralph H. Johnson, eds., Informal logic: the First International Symposium, Inverness, CA, Edgepress, 1980.

Blair, J. Anthony y Ralph H. Johnson, New Essays in Informal Logic, Windsor, Informal Logic Enterprises, 1994.

Blanco, Mercedes, Les Rhétoriques de la Pointe. Baltasar Gracián et le Conceptisme en Europe, Genève, Editions Slatkine, 1992.

Blanco, Mercedes, «Quevedo lector de Malvezzi», La Perinola, 8, 2004, pp. 77108.

Bleznick, Donald W., «La Política de Dios de Quevedo y el pensamiento político en el Siglo de Oro», Nueva Revista de Filología Hispánica, Ix, 1955, pp. 385-394.

Blüher, Karl Alfred, Séneca en España. Investigaciones sobre la recepción de Séneca en España desde el siglo XII hasta el siglo XVII, trad. Juan Conde, Madrid, Gredos, 1983 ( $1^{\text {a }}$ edición, München, 1969).

Bouvier, René, Quevedo, Homme du diable, homme de Dieu, Paris, Honoré Champion, 1929.

Budor, Karlo, "Quevedo y la Guerra de los uscoques: sus fuentes documentales», Revista de Filología Española, Lxxv, 3-4, 1995, pp. 333-344.

Cacho, Rodrigo, "Introducción a la Parte segunda póstuma de la Política de Dios y gobierno de Cristom, en Francisco de Quevedo, Obras completas en prosa, dir. Alfonso Rey, Madrid, Castalia, 2012, vol. v, pp. 327-335.

Cacho, Rodrigo, «Quevedo contra todos: la segunda parte de la Política de Dios y su contexto', Bulletin of Hispanic Studies, 87-88, 2010, pp. 897-920.

Cappelli, Federica, "Ivicio qve de Marco Brvto hizieron los Autores en sus Obras: un estudio de las traducciones quevedianas de los pasajes clásicos», La Perinola, 5, 2001, pp. 69-93.

Carminati, Clizia y Valentina Nider, eds., Narrazione e storia tra Italia e Spagna nel Seicento, Trento, Editrice Università degli Studi di Trento, 2007.

Cerdan, Francis, «Oratoria sagrada y reescritura en el Siglo de Oro: el caso de la homilía», Criticón, 79, 2000, pp. 87-105.

Cicerón, Brutus, ed. bilingüe (latín-francés) de Jules Martha, Paris, Les Belles Lettres, 1931.

Cicerón, De inventione, ed. bilingüe (latín-francés) de Guy Achard, Paris, Les Belles Lettres, 1994.

Cicerón, De Oratore, ed. bilingüe (latín-francés) de Edmond Courbaurd y Henri Bornecque, Paris, Les Belles Lettres, 1927-1938, 3 vols.

Civil, Pierre, «Vies d’hommes illustres et modèle politique. Les discours biographiques de Juan Pablo Mártir Rizo (1625-1633)», en Littérature et Politique en Espagne aux siècles d'Or, ed. Jean-Pierre Étienvre, Paris, Klincksieck, 1998, pp. 363-376.

Clamurro, William H., Language and Ideology in the Prose of Quevedo, Newark, Juan de la Cuesta, 1991. 
Collado Ruiz, María José, «El secretario del rey, Antonio de Aróstegui, a la luz de su testamento: la persona y el personaje», Potestas, 7, 2014, pp. 179-190.

Compagnon, Antoine, La seconde main ou le travail de la citation, Paris, Éditions du Seuil, 1979.

Copeland, Rita, "Roman theories on translation: the fusion on grammar and rhetoric), en Rhetoric, Hermeneutics and Translation in the Middle Ages. Academic Traditions and Vernacular Texts, Cambridge, Cambridge University Press, 1991, pp. 9-36.

Crosby, James O., The Sources of the Text of Quevedo's Politica de Dios, New York, The Modern Language Association of America, 1959.

Curtius, Ernst Robert, Literatura europea y Edad Media latina, trad. Margit Frenk y Antonio Alatorre, México, Fondo de Cultura Económica, 1981, 3ª reimpresión ( $1^{\mathrm{a}}$ edición, Bern, 1948).

Díaz Martínez, Eva María, “Introducción a la Política de Dios, gobierno de Cristo», en Francisco de Quevedo, Obras completas en prosa, dir. Alfonso Rey, Madrid, Castalia, 2012, vol. v, pp. 161-186.

Eemeren, Frans H. Van, y Rob Grootendorst, Argumentation, Communication and Fallacies. A pragma-dialectic perspective, Hilldale, New Jersey, Lawrence Erlbaum Associates, 1992.

Elliott, John H., "Quevedo and the Count-Duke of Olivares», en Quevedo in perspective, ed. James Iffland, Newark, Delaware, Juan de la Cuesta, 1982, pp. 227-250.

Escobar Borrego, Francisco Javier, «A vueltas sobre la tradición retórica en Francisco de Quevedo: la España defendida como monumento propagandístico y de canonización (con un excurso sobre la pervivencia de Quintiliano)», La Perinola, 16, 2012, pp. 165-185.

Escobar Borrego, Francisco Javier, «Técnicas y recursos retóricos en la España defendida de Francisco de Quevedo», Bulletin of Hispanic Studies, 90, 1, 2013, pp. 27-36.

Escobar Borrego, Francisco Javier, «Tradición retórica e Historiografía clásica en la España defendida, de Francisco de Quevedo (con un enfoque comparativo respecto a la Vida de Marco Bruto)",, en Humanismo y Pervivencia del Mundo Clásico. Homenaje al profesor Juan Gil, eds. José Ma Maestre Maestre, Sandra I. Ramos Maldonado, Manuel A. Díaz Gito, M. ${ }^{a}$ Violeta Pérez Custodio, Bartolomé Pozuelo Calero y Antonio Serrano Cueto, Madrid-Alcañiz, csic / Instituto de Estudios Humanísticos, 2015, vol. 3, pp. 1615-1635.

Étienvre, Jean-Pierre, «Pour une histoire de la métaphore politique (quelques suggestions, une singularité et deux exemples», en Littérature et Politique en Espagne aux siècles d'Or, dir. Jean-Pierre Étienvre, Paris, Klincksieck, 1998, pp. 11-27.

Ettinghausen, Henry, «Estilística y política: Quevedo y Almansa ante el cambio de régimen de 1621\%, en Littérature et Politique en Espagne aux siècles d'Or, dir. Jean-Pierre Étienvre, Paris, Klincksieck, 1998, pp. 151-162.

Ettinghausen, Henry, «Ideología intergenérica: la obra circunstancial de Quevedom, en Estudios sobre Quevedo. Quevedo desde Santiago entre dos aniversarios, coord. Santiago Fernández Mosquera, Santiago de Compostela, Universidad, 1995, pp. 225-259.

Ettinghausen, Henry, "Quevedo ante dos hitos en la historia de su tiempo: el cambio de régimen de 1621 y las rebeliones de catalanes y portugueses de 1640\%, en Quevedo a nueva luz: escritura y política, eds. Lía Schwartz y Antonio Carreira, Málaga, Universidad, 1997, pp. 83-109. 
Ettinghausen, Henry, Quevedo neoestoico, Pamplona, Eunsa, 2009 ( $1^{\mathrm{a}}$ edición inglesa, Oxford, 1972).

Fernández Mosquera, Santiago, «El sermón, el tratado, el memorial: la escritura interesada de Quevedom, La Perinola, 2, 1998, pp. 63-86.

Fernández Mosquera, Santiago, «La hora de la reescritura en Quevedo», Criticón, 79,2000 , pp. 65-86.

Fernández Rivera, Enrique, «Fragmentación corporal y exégesis política en Quevedom, La Perinola, 14, 2010, pp. 305-319.

Gendreau, Michèle, Héritage et création: recherches sur l'humanisme de Quevedo, Thèse présentée devant l'Université de Paris iv, Lille / Paris, Librairie Honoré Champion, 1977.

Ghia, Walter, Il pensiero politico de Francisco de Quevedo, Pisa, Edizioni Eтs, 1994.

Ghirardi, Óscar A., "La retórica forense (de los griegos y romanos al siglo xxI)», en El siglo XXI y el razonamiento forense, Córdoba (Argentina), Academia Nacional de Derecho y Ciencias Sociales, 2000, pp. 177-205.

Ghirardi, Óscar A., La retórica y la dialéctica en el razonamiento forense, Santa $\mathrm{Fe}$ de Bogotá, Ediciones Academia Colombiana de Jurisprudencia / Colección Portable, 2001.

Gómez Moreno, Ángel, España y la Italia de los humanistas, Madrid, Gredos, 1994.

González de la Calle, Pedro Urbano, «Quevedo intérprete y continuador de Séneca el retóricom, en Pedro Urbano González de la Calle, Quevedo y los dos Sénecas, México, El Colegio de México, 1965, pp. 1-188.

González Quintas, Elena, La metáfora en la poesía de Quevedo. La naturaleza y la mujer, Pamplona, Eunsa, 2006.

Gracián, Baltasar, Agudeza y arte de ingenio, ed. Evaristo Correa Calderón, Madrid, Castalia, 1987, 2 vols.

Grice, Herberto Paul, «Lógica y conversación», en La búsqueda del significado. Lecturas de filosofía del lenguaje, ed. Luis Valdés Villanueva, Madrid, Tecnos, 1991 (1ª edición, New York, 1975).

Guillén, Claudio, «Quevedo y el concepto retórico de la literatura», en Academia literaria renacentista II. Homenaje a Quevedo, ed. Víctor García de la Concha, Salamanca, Universidad, 1982, pp. 483-506.

Hafter, Monroe H., «Sobre la singularidad de la Política de Dios», Nueva Revista de Filología Hispánica, 13, 1959, pp. 101-104.

Hamblin, Charles Leonard, Fallacies, London, Methuen, 1970.

Hermógenes, véase Teón.

Jauralde Pou, Pablo, «Obras de Quevedo en la prisión de san Marcos», Hispanic Review, 50, 1982, pp. 159-171.

Jauralde Pou, Pablo, Francisco de Quevedo (1580-1645), Madrid, Castalia, 1998.

Juárez, Encarnación, Italia en la vida y obra de Quevedo, New York / Bern / Frankfurt, Peter Lang, 1990.

Juárez, Encarnación, «Quevedo, Contreras, Duque de Estrada y sus conceptos de Mediterráneom, La Perinola, 10, 2006, pp. 361-382.

Krabbenhoft, Kenneth, El precio de la cortesía. Retórica e innovación en Quevedo y Gracián, Salamanca, Universidad, 1994.

Lausberg, Heinrich, Manual de retórica literaria. Fundamentos de una ciencia de la literatura, trad. José Pérez Riesco, Madrid, Gredos, 1984, 3 vols. (1 ${ }^{\text {a }}$ ed. 1966-1969).

León, fray Luis de, Exposición del Libro de Job, ed. Javier San José Lera, Salamanca, Ediciones Universidad de Salamanca, 1992, 2 vols. 
Lida, Raimundo, Prosas de Quevedo, Barcelona, Crítica, 1981.

Llamas Martínez, Jacobo, Tradición y originalidad en la poesía funeral de Quevedo, Vigo, Editorial Academia del Hispanismo, 2016.

López Grigera, Luisa, La Retórica en la España del Siglo de Oro: teoría y práctica, Salamanca, Universidad, 1994.

López Grigera, Luisa, Anotaciones de Quevedo a la "Retórica» de Aristóteles, Salamanca, Gráficas Cervantes, 1998.

López Poza, Sagrario, "Quevedo humanista cristiano», en Quevedo a nueva luz: escritura y política, ed. Lía Schwartz y Antonio Carreira, Málaga, Universidad, 1997, pp. 59-81.

López Poza, Sagrario, Francisco de Quevedo y la Literatura patrística, A Coruña, Universidade da Coruña, 1992.

Luciano de Samosata, Cómo debe escribirse la historia, en Obras, ed. y trad. Juan Zaragoza Botella, Madrid, Gredos, 1990, vol. 3.

Margolin, Jean-Claude, "Le paradoxe est-il une figure Rhétorique?», Nouvelle Revue du $x$ II $^{e}$ siècle, 6,1988 , pp. 5-14.

Martín Pérez, Marciano, Quevedo. Aproximación a su religiosidad, Burgos, Ediciones Aldecoa, 1980.

Martinengo, Alessandro, El «Marco Bruto» de Quevedo, una unidad en dinámica transformación, Bern, Peter Lang, 1998a.

Martinengo, Alessandro, «La muerte de Porcia: ¿un recurso retórico? (de Plutarco al Marco Bruto de Quevedo», en Littérature et Politique en Espagne aux siècles d'Or, dir. Jean Pierre Étienvre, Paris, Klincksieck, 1998b, pp. 409421.

Martinengo, Alessandro, «El tema senequiano de los beneficios y el Marco Bruto de Quevedom, La Perinola, 2, 1998c, pp. 107-115.

Martínez Burgos, M., "Quevedo escriturista: su Política de Dios y Gobierno de Cristom, Boletín de la Biblioteca de Menéndez Pelayo, xxi, 1945, pp. 443-448.

Martínez Millán, José, «Reflexiones en torno a los escritos políticos e históricos de Francisco de Quevedom, La Perinola, 18, 2014, pp. 103-141.

Mathieu-Castellani, Giséle et M. Plaisance, eds., Le commentaire et la naissance de la critique littéraire. France. Italie (XIV-XVI siècles), Paris, Aux Amateurs de Livres, 1990.

Maura, Duque de, «La última obra malograda de Quevedo», Boletín de la Real Academia Española, xxIv, 1945, pp. 335-351.

Momigliano, Arnaldo, The Development of Greek Biography, Cambridge, Massachusetts, Harvard University Press, 1971 (reimpreso en 1993).

Nider, Valentina, "El diseño retórico de la prosa religiosa de Quevedo», en Estudios sobre Quevedo. Quevedo desde Santiago entre dos aniversarios, ed. Santiago Fernández Mosquera, Santiago de Compostela, Universidad, 1995, pp. 207-224.

Nider, Valentina, "Quevedo e l'Ars Historica: le oraciones e le conjeturas», en Narrazione e storia tra Italia e Spagna nel Seicento, a cura di Clizia Carminati e Valentina Nider, Trento, Editrice Università degli Studi di Trento, 2007, pp. 251-287.

Nider, Valentina, «Política y retórica en la Hora de todos: las orationes fictae (con una mirada hacia Marco Bruto)", en Literatura, sociedad y política en el Siglo de Oro, eds. Eugenia Fosalba y Carlos Vaíllo, Bellaterra, Universitat Autònoma de Barcelona, 2010a, pp. 319-334.

Nider, Valentina, «Sarpi, Quevedo e la pubblicistica sulla guerra degli uscocchi», en Giudizi e pregiudizi. Percezione dell'altro e stereotipi tra Europa e 
Mediterraneo. Atti del Seminario. Firenze, 10-14 giugno 2008, a cura di Maria Grazia Profeti, Firenze, Alinea Editrice, 2010b, vol. 1, pp. 211-237.

Nider, Valentina, “Los personajes femeninos y sus orationes fictae en las vidas del xvir: Malvezzi y Mártir Rizo", en Compostella Aurea. Actas del viII Congreso de la AISo, eds. Antonio Azaustre Galiana y Santiago Fernández Mosquera, Santiago de Compostela, Universidad, 2011, vol. 2, pp. 405-412.

Nider, Valentina, «Quevedo y los uscoques: trasfondo histórico de una secuencia de Mundo caducom, en Italia en la obra de Quevedo, ed. María José Alonso Veloso y Alfonso Rey, Santiago de Compostela, usc Editora, 2013a, pp. 123-143.

Nider, Valentina, "Las anotaciones quevedianas a la Catecheses de san Cirilo de Jerusalén», La Perinola, 17, 2013b, pp. 259-299.

Nider, Valentina, "La Relación verdadera... sobre el hecho de los Uscoques de Emanuel de Tordesillas y el Mundo caduco de Francisco de Quevedom, La Perinola, 18, 2014, pp. 143-159.

Peraita, Carmen, «Arte de disimulo y paradoja: la crítica a Felipe III en Grandes anales de quince días de Quevedom, en Actas del XI congreso de la AIH (1992), ed. Juan Villegas, Irvine, University of California Press, 1994, pp. 111-120.

Peraita, Carmen, «From Plutarch's Glossator to Court Historiographer. Quevedo's Interpretative Strategies in Vida de Marco Brutom, Allegorica, 17, 1996, pp. 73-94.

Peraita, Carmen, Quevedo y el joven Felipe IV. El príncipe cristiano y el arte del consejo, Kassel, Reichenberger, 1997.

Peraita, Carmen, «Papel simbólico y función del arte retórico y la práctica hermenéutica en la Política de Dios In, en Siglo de Oro. Actas del IV Congreso de la aIso, eds. María Cruz García de Enterría y Alicia Cordón Mesa, Alcalá de Henares, Universidad de Alcalá, 1998, vol. 2, pp. 1203-1210.

Peraita, Carmen, «La copia erasmiana y la construcción retórica de Política de Dioss, La Perinola, 3, 1999, pp. 209-224.

Peraita, Carmen, «Paradigmas y monarcas: el contexto del ejemplo y el rechazo de la Historia en la Política de Dios de Quevedom, en Estudios de filología y retórica en homenaje a la profesora Luisa López Grigera, coords. Elena Artaza, Javier Durán, Carmen Isasi, Jamile Lawand, Victoria Pineda y Fernando Plata, Bilbao, Universidad de Deusto, 2000, pp. 355-369.

Peraita, Carmen, «La oreja, lengua, voz, el grito y las alegorías del acceso al rey: elocuencia sacra y afectos políticos en Política de Dios de Quevedo», La Perinola, 5, 2001, pp. 185-205.

Perelman, Charles y Lucie Olbrehts-Tyteca, Tratado de la argumentación. La nueva retórica, trad. Julia Sevilla Muñoz, Madrid, Gredos, 1994 ( $1^{\text {a }}$ edición, Bruselas, Éditions de l'Université de Bruxelles, 1989).

Pérez Carnero, Celso, Moral y Política en Quevedo, Orense, Gráficas Tanco, 1970 (extracto de su Tesis Doctoral).

Pérez Carnero, Celso, Moral y Política en Quevedo, Ourense, Instituto Teológico Divino Maestro, 2007.

Pérez Cuenca, Isabel, «Las lecturas de Quevedo a la luz de algunos impresos de su biblioteca", La Perinola, 7, 2003, pp. 297-333.

Pérez Cuenca, Isabel, «Localización y descripción de algunos impresos de la biblioteca de Quevedom, en Actas del XIV Congreso de la AIH. II. Literatura Española, Siglos XVI y XVII, ed. Isaías Lerner, Robert Nival y Alejandro Alonso, Newark-Delaware, Juan de la Cuesta, 2004, pp. 447-465.

Plantin, Christian, La argumentación, trad. Amparo Tusóns Valls, Barcelona, Ariel, 1998 (1 ${ }^{\text {a }}$ edición, París, 1996). 
Plata Parga, Fernando, «Edición de las Controversias de Séneca, texto inédito de Francisco de Quevedom, La Perinola, 5, 2001, pp. 207-275.

Quevedo, Francisco de, Discurso de las privanzas, ed. Eva María Díaz Martínez, Pamplona, Eunsa, 2000.

Quevedo, Francisco de, Epistolario completo, ed. Luis Astrana Marín, Madrid, Instituto Editorial Reus, 1946.

Quevedo, Francisco de, Grandes de quince días, ed. Victoriano Roncero López, en Obras completas en prosa, dir. Alfonso Rey, Madrid, Castalia, 2005, vol. III, pp. 43-115.

Quevedo, Francisco de, La caída para levantarse. El ciego para dar vista, el montante de la Iglesia en la vida de san Pablo Apóstol, ed. Valentina Nider, Pisa, Giardini, 1994.

Quevedo, Francisco de, Mundo caduco y desvaríos de la edad en los años de 1613 hasta 1620, ed. Victoriano Roncero López en Obras completas en prosa, dir. Alfonso Rey, Madrid, Castalia, 2005, vol. III, pp. 117-183.

Quevedo, Francisco de, Mundo caduco, ed. Javier Biurrun Lizarazu Pamplona, Eunsa, 2000.

Quevedo, Francisco de, Obra poética, ed. José Manuel, Blecua, Madrid, Castalia, 1969-1981, 4 vols.

Quevedo, Francisco de, Obras en prosa, ed. Luis Astrana Marín, Madrid, Aguilar, 1932.

Quevedo, Francisco de, Política de Dios, ed. Eva María Díaz Martínez y Rodrigo Cacho Casal en Obras completas en prosa, dir. Alfonso Rey, Madrid, Castalia, 2012, vol v, pp. 159-639.

Quevedo, Francisco de, Primera parte de la vida de Marco Bruto, ed. María José Alonso Veloso en Obras completas en prosa, dir. Alfonso Rey, Madrid, Castalia, 2012, vol. v, pp. 641-984.

Quevedo, Francisco de, Virtud militante contra las cuatro pestes del mundo: invidia, ingratitud, soberbia, avaricia, ed. Alfonso Rey en Obras completas en prosa, dir. Alfonso Rey, Madrid, Castalia, 2010, vol. IV.

Quintiliano, Institutio Oratoria, ed. bilingüe (latín-francés) de Jean Cousin, Paris, Les Belles Lettres, 1975-1980, 7 vols.

Redondo, Augustin, ed., Le corps comme métaphore dans l'Espagne des XVI et XVII siècles, Paris, Publications de la Sorbonne, 1992.

Rey, Alfonso, «Los memoriales de Quevedo a Felipe IV», Edad de Oro, XII, 1993, pp. 257-65.

Rey, Alfonso, “Introducción», en Francisco de Quevedo, Obras completas en prosa, Madrid, Castalia, 2005, vol. III, pp. XVII-LXIV.

Rey, Alfonso, «Introducción», en Francisco de Quevedo, Obras completas en prosa, Madrid, Castalia, 2012, vol. v, pp. 11-83.

Rhetorica ad Herennium, ed. bilingüe (latín-francés) de Guy Achard, Paris, Les Belles Lettres, 1989.

Riandière La Roche, Josette, «Recherches sur la structure de La Vida de Marco Bruto», Les Langues Néo-latines, 117, 1976, pp. 50-73.

Riandière La Roche, Josette, “Corps politique et corps mystique dans la Politica de Dios de Quevedo", en Le corps comme métaphore dans l'Espagne des XVI et XVII ${ }^{e}$ siècles, ed. Augustin Redondo, Paris, Publications de la Sorbonne, 1992, pp. 115-133.

Riandière La Roche, Josette, «Quevedo, historiador y libelista», en Hommage à Robert Jammes, ed. Francis Cerdan, Toulouse, Presses Universitaires du Mirail, 1994, vol III, pp. 977-993. 
Riandière La Roche, Josette, «Entender y anotar los textos políticos de Quevedo: las exigencias de la Historia», La Perinola, 4, 2000, pp. 345-366.

Roig, Miranda, Marie, Le paradoxe dans la Vida de Marco Bruto de Quevedo, Paris, École Normale Supérieure de Jeunes Filles, 1980.

Roncero López, Victoriano, Los Grandes anales de quince días de Quevedo. Edición y estudio, Madrid, Editorial de la Universidad Complutense, 1988.

Roncero López, Victoriano, Historia y política en la obra de Quevedo, Madrid, Pliegos, 1991.

Roncero López, Victoriano, «Un enigma historiográfico: el Mundo caduco y los Grandes analess, Edad de Oro, 13, 1994, pp. 151-160.

Roncero, López, Victoriano, «Introducción a Mundo caduco y desvaríos de la edad en los años de 1613 hasta 1620\%, en Obras completas en prosa, dir. Alfonso Rey, Madrid, Castalia, 2005, vol. III, pp. 119-127.

Roncero López, Victoriano, «El discurso histórico quevediano y el inicio de la Guerra de los Treinta Años: Mundo caduco y desvaríos de la edads, La Perinola, 18, 2014, pp. 161-179.

Rovira Flórez de Quiñones, María Carolina, «De la retórica antigua a la argumentación contemporánea», en La argumentación jurídica. Problemas de concepto, método y aplicación, ed. Francisco Puy Muñoz y Jorge Guillermo Portela, Santiago de Compostela, Universidad, 2004, pp. 214-235.

Schwartz, Lía, Metáfora y sátira en la obra de Quevedo, Madrid, Taurus, 1984.

Schwartz, Lía, Quevedo: discurso y representación, Pamplona, Eunsa, 1986.

Schwartz, Lía, «Un género historiográfico del siglo xvir: las Vidas de Juan Pablo Mártir Rizo», Studi Ispanici, 1, 2005, pp. 85-102.

Schwartz, Lía, «La Historia de la vida de un ilustre romano: Séneca según J. P. Mártir Rizo", en Narrazione e storia tra Italia e Spagna nel Seicento, a cura di Clizia Carminati e Valentina Nider, Trento, Editrice Università degli Studi di Trento, 2007, pp. 165-183.

Searle, John, Actos de habla; ensayo de filosofía del lenguaje, trad. Luis Valdés, Madrid, Cátedra, 1994 ( $1^{\text {a }}$ edición, Cambridge, 1969).

Teón, Hermógenes, Aftonio, Ejercicios de retórica, trad. M. ${ }^{a}$ Dolores Reche Martínez, Madrid, Gredos, 1991.

Vaíllo, Carlos, “Imágenes matemáticas y economía del discurso en la Vida de Marco Bruto de Quevedo", en Littérature et Politique en Espagne aux siècles d’Or, dir. Jean Pierre Étienvre, Paris, Klincksieck, 1998, pp. 393-407.

Vaíllo, Carlos, «La anotación y edición de la Vida de Marco Bruto de Quevedo», La Perinola, 4, 2000, pp. 393-414.

Vaíllo, Carlos, «Historia y ficción en el siglo Xviı», en Narrazione e storia tra Italia e Spagna nel Seicento, a cura di Clizia Carminati e Valentina Nider, Trento, Editrice Università degli Studi di Trento, 2007, pp. 7-36.

Woods, John y Douglas Walton, Critique de l'argumentation, Paris, Kimé, 1992. 


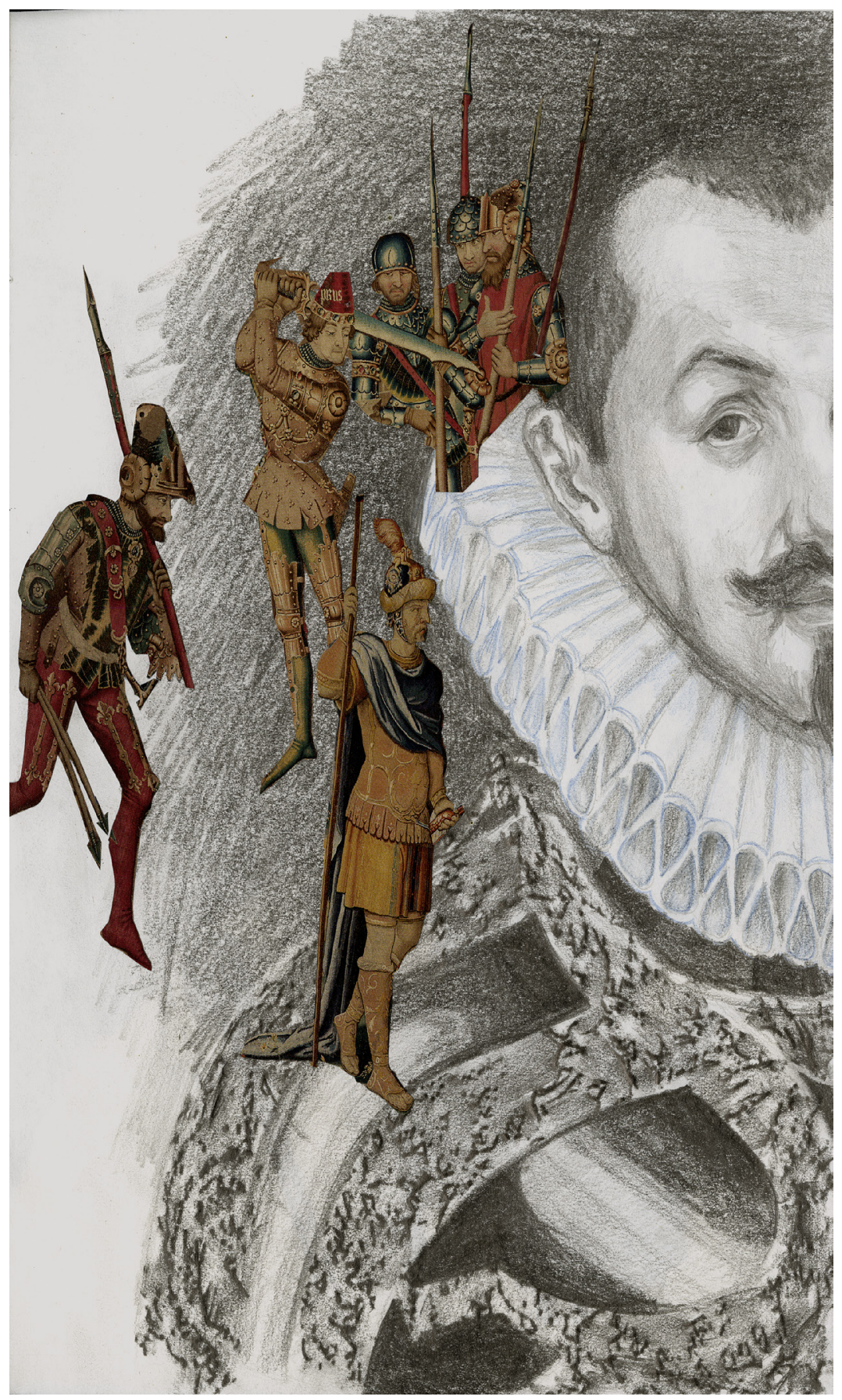


